Revista lus et Praxis, Año 23, No 2, 2017, pp. 251 - 294

ISSN 0717 - 2877

Universidad de Talca - Facultad de Ciencias Jurídicas y Sociales

Cuatro versiones de la Nulidad de Derecho Público.

Primera parte: La versión de Mario Bernaschina González

Claudio Agüero San Juan

Trabajo recibido el 20 de enero de 2015 y aprobado el 29 de septiembre de 2015

\title{
Cuatro versiones de la Nulidad de Derecho Público. Primera parte: La versión de Mario Bernaschina González*
}

\author{
Four Versions of PUblic laW ANNUlment. Part one: \\ The contribution of Mario Bernaschina González
}

Claudio Agüero San Juan**

\begin{abstract}
RESUMEN
El objetivo es mostrar que los juristas atribuyen diferentes significados a un mismo conjunto de disposiciones constitucionales usando combinaciones discrecionales de conceptos dogmáticos y directivas hermenéuticas. Para ello reconstruye la argumentación dogmática Ilamada "Nulidad de Derecho Público" en el trabajo de Bernaschina (1949), porque la doctrina lo considera el creador de esta argumentación. El método de análisis aplica las categorías postuladas por Tarello y sus continuadores en la Escuela Genovesa de Teoría del Derecho a la dogmática chilena. La conclusión sostiene que la "Nulidad de Derecho Público" es Derecho Administrativo vigente de creación extralegislativa por la vía de recurrir a combinaciones diferentes de conceptos dogmáticos y de directivas hermenéuticas.
\end{abstract}

ABSTRACT

The aim is to show that jurists attribute different meanings to the same set of constitutional texts discretionary using combinations of dogmatic concepts and hermeneutical rules. Four this reconstructs the dogmatic argument called "public law annulment" at work Bernaschina (1949), because the doctrine is considered the creator of this argument. The analysis method applies the categories postulated by Tarello and his followers in the Genovese School of Theory of Law Chilean dogmatic. The conclusion argues that the 'public law annulment' is applicable Administrative Law extralegislativa creation by way of using different combinations of dogmatic concepts and hermeneutical rules.

\section{Palabras Clave}

Nulidad de Derecho público, Creación extralegislativa del Derecho público, Dogmática chilena, Interpretación constitucional, Jurisprudencia sociológica

\footnotetext{
* Investigación realizada en el marco del Proyecto Fondecyt № 1140982, titulado Análisis diacrónico de la influencia de las labores dogmáticas en las tareas judiciales: el caso de la "nulidad de derecho público" (1990-2005).

** Abogado. Magíster en Derecho por la Universidad de Génova. Doctor en Ciencias Humanas con mención en discurso y cultura por la Universidad Austral de Chile. Profesor de las universidades Diego Portales y Alberto Hurtado (Chile). Correspondencia a Cienfuegos 41, Santiago Centro, Chile. Correo electrónico: aguero.claudio@gmail.com.
} 
KEY WORDS

Public law annulment; Public law created in an extra legislative way, Chilean legal dogmatic, Constitutional interpretation, Sociological jurisprudence

\section{INTRODUCCIÓN}

Este es un artículo de Teoría del Derecho cuyo objeto de análisis es un fenómeno dogmático en el derecho chileno. El modo de hacer el análisis tiene un fuerte influjo de la Escuela de Génova y, específicamente, de las obras de Tarello, Guastini, Barberis, Comanducci y Chiassoni. En razón de esta perspectiva, antes de iniciar advierto al lector que no busque aquí propuestas, soluciones o progresos en torno al fenómeno estudiado. Tal como lo señala Tarello, la Teoría del Derecho es "una investigación sobre los métodos y las valoraciones de los juristas, [que] si quiere tener utilidad, no debe ocuparse de dar sugerencias a los juristas en general, ni de recopilar lo que grupos de juristas dice realizar (a título de teoría), sino que debe ocuparse de las operaciones conceptuales que ciertos juristas han realizado en determinadas circunstancias" ${ }^{\prime 1}$. La Teoría del Derecho, según se argumenta más adelante, es fatalmente retrospectiva.

El artículo es la primera parte de un total de tres. Todos reconstruyen el desarrollo de las normas chilenas sobre la acción de control de la legalidad de las actuaciones de la administración. A nivel local, este subconjunto de normas permiten a los ciudadanos controlar la legalidad del actuar de la administración² es Ilamado "Nulidad de Derecho público" y, a veces, "Acción de Nulidad de Derecho público" o "Acción Constitucional de derecho público" (en adelante uso la abreviatura NDP como referencia general solo por simplicidad). El desarrollo de este subconjunto de normas es el objeto de estudio de esta investigación.

La reconstrucción tiene dos propósitos. El primero es teórico o metadogmático. Justificar la tesis que afirma que las normas chilenas que sustentan

\footnotetext{
1 TARello (2002), p. 10.

${ }^{2}$ Lo que en Chile se llama NDP en el Derecho Comparado se conoce como control de la legalidad de los actos administrativos. Al respecto, RaJeVIC y Garcés (2009), p. 63, dicen: "Acción de nulidad de derecho público. Se trata de un procedimiento ideado por la doctrina que permite declarar la nulidad de un acto administrativo a través de un juicio declarativo ordinario, seguido conforme a las reglas del procedimiento común. Por ello podría calificarse de un contencioso anulatorio general en materia contencioso administrativa, con las dificultades de carecer de una regulación específica para estos efectos". Al finalizar el párrafo citado los autores citan a Fiamma (1986a); Sото (1996), pp. 179-194, y JaRA (2004). Con mayor actualidad, por todos, ver Bermúdez (2008), Bermúdez (2010), Bermúdez (2012), Letelier (2013).
} 
la existencia de la NDP fueron desarrolladas, creadas o inventadas ${ }^{3}$ por los juristas a partir de la interpretación correctora de un conjunto de disposiciones constitucionales que no sufre grandes cambios a lo largo del tiempo ${ }^{4}$. Esta es una tesis descriptiva sobre un problema específico del Derecho Administrativo chileno en un rango determinado de tiempo.

Este es un propósito metadogmático en no menos de tres sentidos. Primero, esto quiere decir que la investigación no formula propuestas sobre cuál de las posiciones dogmáticas analizadas es la más coherente, correcta, adecuada o trajo las mejores consecuencias normativas. Segundo, la investigación asume sin cuestionamientos que el uso pretérito de ciertos conceptos o etiquetas dogmáticas por parte de los juristas es el principal criterio de ajuste de las afirmaciones que la investigación realiza sobre el Derecho Administrativo chileno en una mirada retrospectiva. Tercero, la investigación no dice nada sobre los problemas normativos que trae para el sistema jurídico la existencia de facto de un sistema de doble o triple legalidad (el legislador dice A y los juristas interpretan diciendo $A_{1}, A_{2}, A_{3^{\prime}}$ etc. y los jueces resuelven $A_{1}, B_{2}, C_{7} O$ $A_{2}$ ) porque este es un problema normativo que demanda una propuesta que excede los límites de esta investigación.

El segundo propósito de la investigación es metodológico. Consiste en probar que algunas categorías de análisis postuladas por la Escuela Genovesa de Teoría del Derecho ${ }^{5}$ no son vacías si se observa la dogmática chilena sobre la NDP. Así, la reconstrucción del desarrollo de la NDP permite probar qué fragmentos del discurso dogmático sobre esa figura pueden ser reconstruidos como instancias de las taxonomías genovesas sobre la interpretación. En este sentido, la investigación es un ejercicio de aplicación de las clasificaciones y los modelos genoveses. Este ejercicio implica crear criterios de identificación de estas categorías en los textos dogmáticos analizados. En alguna medida, los criterios de identificación son el resultado incompleto de la investigación, porque un ejercicio de aplicación de este tipo no ha sido realizado previamente sobre textos de dogmática chilena.

El artículo se compone de cuatro partes. La primera se encarga de fijar las disposiciones normativas básicas que se usan en el desarrollo de la NDP. Creo que el lector familiarizado con la dogmática puede omitir su lectura sin

\footnotetext{
3 Uso el verbo "inventar" en el sentido filosófico con que lo usa en otro contexto TorretTI (2010); TORETTI (2012).

${ }^{4}$ Como es obvio, la posición estándar no es homogénea y hay disputas sobre los elementos del razonamiento interpretativo.

${ }^{5}$ BARBeRIS (2011), p. 201.
} 
mayores pérdidas. La segunda parte define someramente las categorías genovesas usadas para el análisis. En este ejercicio se hacen explícitos los criterios de identificación de las categorías en el discurso dogmático sobre la NDP. La tercera parte aplica las categorías genovesas a la obra de Bernaschina y las examina con detalle con el fin de hacer explícitas las piezas que forman su argumentación. Esta parte enfatiza el análisis del código hermenéutico y las categorías dogmáticas implicadas en el discurso dogmático, porque ellas serán usadas luego para comparar las diversas versiones de la NDP. La cuarta parte expone las conclusiones.

\section{Los textos constitucionales en el desarrollo de la NDP}

Este apartado resume las principales reformas constitucionales y cambios legislativos que afectaron a las disposiciones normativas involucradas en el discurso dogmático estudiado. El texto de la Constitución de 1833 contenía dos disposiciones sobre el asunto investigado: los artículos 159 y 160. Con la reforma constitucional del 9 de agosto de 1888 se cambió la numeración y los artículos quedaron con los números 150 (159) y 151 (160). El texto de ambos artículos no fue modificado durante la vigencia de esa Constitución. La Constitución de 1925 cambió la ubicación de estos dos artículos: el artículo 150 (159) pasó a ser el artículo $3^{\circ}$ y el artículo 151 (160) tomó la ubicación del artículo $4^{\circ}$. La redacción de ambos cambió solo mínimamente: en el artículo 150 (159) el verbo "puede" fue reemplazado por "pueden" y la preposición "a" por "en". En el artículo 151 (160) el verbo "haya" fue sustituido por "hayan".

Con posterioridad al golpe militar de 1973, la dictadura de Augusto Pinochet formó una Comisión de Estudios para la Nueva Constitución (abreviada como CENC). Ella redactó el primer borrador de la Constitución de 1980. Esta comisión tomó como base los artículos $3^{\circ}$ y $4^{\circ}$ de la Constitución de 1925 para escribir los artículos $6^{\circ}$ y $7^{\circ}$. En lo que interesa para esta investigación, fueron creados por la CENC el inciso primero y la última frase del inciso cuarto del artículo $7^{\mathrm{o} 6}$. A estos dos artículos es necesario agregar otros dos: el artículo 76 fijo el principio de inexcusabilidad de los jueces, y el inciso $2^{\circ}$ del artículo 38, que estableció la creación de tribunales contencioso-administrativos. El primero de estos artículos no ha recibido modificaciones desde 1980 y el segundo fue derogado con la reforma constitucional de 1989.

El problema de la existencia de tribunales contencioso-administrativos tiene su origen antes de la Constitución de 1925. Durante la vigencia de esta

${ }^{6}$ La frase es "y originará la responsabilidad y sanciones que la ley señale". 
Constitución el artículo 87 ordenaba al legislador crearlos. Ello no ocurrió y ese artículo fue Ilamado "norma programática" por la doctrina. Ante esta inactividad del legislador, los tribunales, en muchas ocasiones, rechazaron demandas interpuestas por particulares en contra del Estado en razón de falta de su competencia fundada en el artículo 38 inciso $2^{\circ}$. Hubo un cambio parcial de esta tendencia entre 1970 y 19737. Con el advenimiento de la dictadura militar los tribunales retomaron la tesis de que no podían juzgar las demandas contra el Estado, porque la Constitución reservaba esa materia a tribunales contencioso-administrativos (iparadojalmente inexistentes!). La reforma constitucional de 1989 liberó esa traba interpretativa al derogar el inciso $2^{\circ}$ del artículo 38. Los tribunales contencioso-administrativos nunca fueron creados $^{8}$.

Desde 1990 hasta el año 2005 se aprobaron 13 mensajes presidenciales con modificaciones al texto constitucional que no afectaron las disposiciones constitucionales implicadas en el asunto que se estudia9 ${ }^{9}$. Ese año entró en vigencia una importante reforma a la Constitución de 1980 y algunos dogmáticos sostuvieron que ella era una nueva Constitución y la restauración de una vieja filosofía constitucional de la república ${ }^{10}$. Por razones que no es posible explicar aquí, ese intento de mejorar la legitimación, del texto de la Constitución de 1980 fracasó y hoy Chile está iniciando un proceso constituyente ${ }^{11}$.

\footnotetext{
7 Sin embargo, hay excepciones importantes como el fallo del Tribunal Especial del Cobre de 11 de agosto que declara inaplicables los recursos interpuestos por Braden Copper Company, Chile Exploration Company y Andes Copper Mining Company. Sentencia recopilada por Evans (1973), pp. 180-192.

${ }^{8}$ A juicio de Ferrada, no hubo una radical indefensión por la ausencia de estos tribunales. En opinión de este autor, durante el siglo XX los tribunales civiles ordinarios siempre conocieron del contencioso reparatorio de carácter patrimonial y los tribunales ordinarios no se negaron a resolver conflictos específicos de ilegalidad de determinados actos de la Administración (el Reclamo de Ilegalidad Municipal). Desde la década de los 60 del siglo XX, resalta Ferrada, los tribunales ordinarios habían empezado a conocer de pretensiones anulatorias (o de inaplicabilidad) de actos administrativos ilegales vía Recurso de Inaplicabilidad. FerRADA (2005).

${ }^{9}$ Fuentes (2010).

10 ZaPata señala: "Más que hablar de una 'nueva' filosofía constitucional, entonces, cabría decir que las reformas de 2005 han vuelto a instalar en la Constitución la 'vieja' filosofía constitucional de nuestra República, la de 1810, 1833, 1925 y 1988: la democracia". Zapata (2006), p. 83.

11 En el plano de las modificaciones legales es necesario destacar que, en este período, los gobiernos de la Concertación de Partidos por la Democracia promulgaron importantes leyes de Derecho Administrativo. Entre ellas se destacan: la Ley sobre Bases Generales de los Procedimientos Administrativos (No 19.880), LBGPA, y la Ley sobre Acceso a la Información Pública (№ 20.285).
} 
Tabla resumen de las disposiciones normativas

\begin{tabular}{|c|c|c|}
\hline Constitución de 1833 & Constitución de 1925 & $\begin{array}{l}\text { Constitución de } 1980 \\
\text { (antes de la reforma de 1989) }\end{array}$ \\
\hline $\begin{array}{l}\text { Art. } 150 \text { (159). Ninguna perso- } \\
\text { na o reunión de personas pue- } \\
\text { de tomar el título o representa- } \\
\text { ción del pueblo, arrogarse sus } \\
\text { derechos, ni hacer peticiones } \\
\text { a su nombre. La infracción de } \\
\text { este artículo es sedición. }\end{array}$ & $\begin{array}{l}\text { Art. } 3^{\circ} \text {. Ninguna persona o re- } \\
\text { unión de personas pueden to- } \\
\text { mar el título o representación } \\
\text { del pueblo, arrogarse sus dere- } \\
\text { chos, ni hacer peticiones en su } \\
\text { nombre. La infracción de este } \\
\text { artículo es sedición. }\end{array}$ & $\begin{array}{l}\text { Art. } 6^{\circ} \text {. Los órganos del Estado } \\
\text { deben someter su acción a la } \\
\text { Constitución y a las normas } \\
\text { dictadas conforme a ella. Los } \\
\text { preceptos de esta Constitución } \\
\text { obligan tanto a los titulares o } \\
\text { integrantes de dichos órganos } \\
\text { como a toda persona, institu- } \\
\text { ción o grupo. } \\
\text { La infracción de esta norma } \\
\text { generará las responsabilidades } \\
\text { y sanciones que determine la } \\
\text { ley. }\end{array}$ \\
\hline $\begin{array}{l}\text { Art. } 151 \text { (160). Ninguna ma- } \\
\text { gistratura, ninguna persona, ni } \\
\text { reunión de personas pueden } \\
\text { atribuirse, ni aún a pretexto de } \\
\text { circunstancias extraordinarias, } \\
\text { otra autoridad o derechos que } \\
\text { los que expresamente se les } \\
\text { haya conferido por las leyes. } \\
\text { Todo acto en contravención a } \\
\text { este artículo es nulo. }\end{array}$ & $\begin{array}{l}\text { Art. } 4^{\circ} \text {. Ninguna magistratura, } \\
\text { ninguna persona, ni reunión } \\
\text { de personas pueden atribuirse, } \\
\text { ni aún a pretexto de circuns- } \\
\text { tancias extraordinarias, otra } \\
\text { autoridad o derechos que los } \\
\text { que expresamente se les hayan } \\
\text { conferido por las leyes. } \\
\text { Todo acto en contravención a } \\
\text { este artículo es nulo. }\end{array}$ & $\begin{array}{l}\text { Art. } 7^{\circ} \text {. Los órganos del Esta- } \\
\text { do actúan válidamente previa } \\
\text { investidura regular de sus inte- } \\
\text { grantes, dentro de su compe- } \\
\text { tencia y en la forma que pres- } \\
\text { criba la ley. } \\
\text { Ninguna magistratura, ningu- } \\
\text { na persona ni grupo de perso- } \\
\text { nas pueden atribuirse, ni aun } \\
\text { a pretexto de circunstancias } \\
\text { extraordinarias, otra autoridad } \\
\text { o derechos que los que expre- } \\
\text { samente se les haya conferido } \\
\text { en virtud de la Constitución o } \\
\text { de las leyes. } \\
\text { Todo acto en contravención a } \\
\text { este artículo es nulo y origina- } \\
\text { rá las responsabilidades y san- } \\
\text { ciones que la ley señale. }\end{array}$ \\
\hline & $\begin{array}{l}\text { Art. 23. Toda resolución que } \\
\text { acordare el Presidente de la } \\
\text { República, la Cámara de Di- } \\
\text { putados, el Senado o los Tribu- } \\
\text { nales de Justicia, a presencia } \\
\text { o requisición de un ejército, } \\
\text { de un jefe al frente de fuerza } \\
\text { armada o de alguna reunión } \\
\text { del pueblo que, ya sea con ar- } \\
\text { mas o sin ellas, desobedeciere } \\
\text { a las autoridades, es nula de } \\
\text { derecho y no puede producir } \\
\text { efecto alguno. }\end{array}$ & \\
\hline
\end{tabular}




\begin{tabular}{|l|l|l|}
\hline \multicolumn{3}{|c|}{ Tabla resumen de las disposiciones normativas } \\
\hline \multirow{4}{*}{ Constitución de 1833 } & \multicolumn{1}{|c|}{ Constitución de 1925 } & $\begin{array}{c}\text { Constitución de 1980 } \\
\text { (antes de la reforma de 1989) }\end{array}$ \\
\hline \multirow{7}{*}{$\begin{array}{l}\text { Art. 75. Todas las órdenes del } \\
\text { Presidente de la República de- } \\
\text { berán firmarse por el Ministro } \\
\text { del departamento respectivo, } \\
\text { y no serán obedecidas sin este } \\
\text { esencial requisito. }\end{array}$} & $\begin{array}{l}\text { Art. 35. Los reglamentos y de- } \\
\text { cretos del Presidente de la Re- } \\
\text { pública deberán firmarse por el } \\
\text { Ministro respectivo y no serán } \\
\text { obedecidos sin este esencial } \\
\text { requisito. }\end{array}$ \\
\hline $\begin{array}{l}\text { Art. 87. Habrá Tribunales Ad- } \\
\text { ministrativos, formados con } \\
\text { miembros permanentes, para } \\
\text { resolver las reclamaciones que } \\
\text { se interpongan contra los ac- } \\
\text { tos o disposiciones arbitrarias } \\
\text { de las autoridades políticas o } \\
\text { administrativas y cuyo cono- } \\
\text { cimiento no esté entregado a } \\
\text { otros Tribunales por la Cons- } \\
\text { titución o las leyes. Su orga- } \\
\text { nización y atribuciones son } \\
\text { materia de ley. }\end{array}$ & $\begin{array}{l}\text { Artículo 38, inciso 2 }{ }^{\circ} \text {. Cual- } \\
\text { quier persona que sea lesio- } \\
\text { nada en sus derechos por la } \\
\text { Administración del Estado, de } \\
\text { sus organismos o de las mu- } \\
\text { nicipalidades, podrá reclamar } \\
\text { ante los tribunales contencio- } \\
\text { so administrativos que deter- } \\
\text { mine la ley, sin perjuicio de la } \\
\text { responsabilidad que pudiere } \\
\text { afectar al funcionario que hu- } \\
\text { biere causado el daño (deroga- } \\
\text { do en 1989). }\end{array}$ \\
\hline
\end{tabular}

\section{Un modelo para análisis de la doctrina sobre la interpretación constitucional de la NDP}

\section{Un modelo realista de interpretación constitucional}

Ocuparse del rol de juristas en el sistema jurídico implica correlacionar personas, ideas y textos y fijar esa correlación en el tiempo para dotarla de un contexto social y político. La complejidad de esta tarea recomienda realizarla por partes. He dejado de lado la contextualización de la obra de Bernaschina por esta razón. Así, en este apartado asumo la tarea de fijar las categorías de análisis que permiten un examen detallado del discurso dogmático.

Un análisis metodológicamente transparente ${ }^{12}$ de la NDP tiene que dar cuenta de las categorías usadas para el análisis y de los modos de identificación de ellas en las argumentaciones de los juristas. Para este ejercicio de

\footnotetext{
12 David Quintero cuestionó el uso de esta expresión y otros aspectos del trabajo en un curso del programa de Doctorado de la Universidad de Valparaíso en donde se discutió una versión previa de este texto. Agradezco sus lúcidas críticas. Aclaro aquí que la expresión implica un baremo mínimo: explicitar los prejuicios y compromisos de quien investiga.
} 
aplicación he usado las siguientes categorías: a) La taxonomía de modelos de interpretación de la Constitución de Comanducci ${ }^{13}$, b) El modelo de código hermenéutico y el modelo de interpretación doctrinal de la Constitución de Chiassoni ${ }^{14}$ y c) Un elenco de categorías (re)construidas a partir de ideas fragmentarias de la Escuela Genovesa. Es claro que este conjunto de categorías no es homogéneo ni sistemático, pues ellas corresponden a contribuciones realizadas por autores diferentes en momentos distintos. Existen superposiciones, vacíos y vaguedades que hay que superar. Sin embargo, creo que la existencia de rasgos teóricos comunes permite reunirlas con el único propósito de obtener un análisis fino del discurso dogmático. Con todo, la honestidad intelectual exige reconocer explícitamente que lo que sigue puede ser interpretado como un apócrifo; el resultado de subvertir lo afirmado por los autores citados orientándolo a mis propios fines específicos. Como es obvio, no realizo una reconstrucción detallada de cada categoría, en razón de que las contribuciones de cada autor han sido publicadas, están suficientemente difundidas y los he citado profusamente.

a) Taxonomía de modelos de Constitución de Comanducci. Los modelos de Constitución de Comanducci son cuatro. Según el autor, estos modelos recogen las concepciones doctrinales más extendidas sobre lo que es una constitución. A su vez, las configuraciones de los cuatro modelos deriva de opciones metodológicas o ideológicas previas y cada uno de los modelos reconoce la posibilidad de abarcar un amplio espectro de conceptos. Para delimitar cada uno de los modelos se usan las funciones que se supone que desarrollan (o deben desarrollar) los objetos designados con el término "constitución"15.

El primer modelo es axiológico de la constitución como orden (natural). En él la constitución designa "un conjunto de fenómenos sociales (entendida esta expresión en su sentido más amplio) que, en su conjunto y dentro de la esfera jurídico-política, aparecen dotados de máximo valor intrínseco o se presentan como generadores de normas ${ }^{\prime \prime 6}$. Para Comanducci, un ejemplo de este modelo es el concepto de constitución de Schmitt.

El segundo modelo es descriptivo de la constitución como orden (artificial). La constitución designa un conjunto de fenómenos sociales que

\footnotetext{
13 Comanducci (2007).

${ }^{14}$ ChIASSONI (2011).

15 Comanducci (2007), p. 40.

${ }^{16}$ Comanducci (2007), p. 40.
} 
no poseen valor intrínseco ni capacidad de generar normas ${ }^{17}$. A juicio de Comanducci, las investigaciones sociológicas y politológicas que describen cómo la estructura fundamental de la sociedad es creada y cambiada por la cooperación y el enfrentamiento entre los grupos de poder son ilustrativas de este modelo ${ }^{18}$.

El tercer modelo es descriptivo de la constitución como norma ${ }^{19}$. Este modelo no considera la existencia de una diferencia cualitativa entre la constitución y las otras normas del sistema jurídico. Para Comanducci, es claro que este modelo está tensionado por dos polos: aquel que distingue a la constitución por una propiedad formal (como los procedimientos de reforma) y aquel que identifica a la constitución con un contenido normativo específico, ya sea un sistema de producción del derecho, con normas que organizan o instituyen los máximos poderes del Estado o con las normas que identifican los fines globales del régimen ${ }^{20}$. En este segundo polo, Comanducci reconoce una diferencia de grado entre los conceptos cercanos a Kelsen y los conceptos políticos según los cuales la Constitución es la norma que tutela determinados derechos y libertades individuales ${ }^{21}$. Con todo, el mismo autor advierte que las concepciones políticas de Constitución se clasifican en el cuarto modelo, en la medida en que ellas valoren positivamente que la Constitución tenga como finalidad tutelar las libertades fundamentales ${ }^{22}$.

El cuarto modelo es axiológico de la Constitución como norma. La Constitución designa a un objeto idéntico que el tercer modelo, al que se adiciona una condición: "que posean determinados contenidos a los que se atribuye un valor específico ${ }^{\prime 23}$. En este modelo la Constitución es, en sí misma, un valor ${ }^{24}$.

\footnotetext{
17 Constitución equivale a la estructura fundamental de la sociedad y/o del Estado y también puede designar "a los elementos más relevantes del sistema social y/o del sistema político". ComanducCI (2007), p. 41.

${ }^{18}$ Comanducci (2007), p. 46.

19 La Constitución designa a un "conjunto de reglas jurídicas positivas, consuetudinarias o expresadas en un documento que, respecto de otras reglas jurídicas, son fundamentales (es decir, fundantes de todo ordenamiento jurídico y/o jerárquicamente superiores a las otras reglas)". ComANDuCCI (2007), p. 41.

${ }^{20}$ Comanducci (2007), p. 50.

21 Comanducci (2007), p. 50.

${ }^{22}$ Comanducci (2007), p. 51.

${ }^{23}$ Comanducci (2007), p. 41.

${ }^{24}$ Adhieren a este modelo, según Comanducci, autores como Dworkin, Habermas, Nino y Alexy. Comanducci (2007), p. 53.
} 
b) El modelo de interpretación doctrinal de la Constitución de Chiassoni ${ }^{25}$. Los modelos de interpretación de la Constitución de Chiassoni son dos. Un modelo operativo que representa las actividades realizadas por el juez constitucional y un modelo doctrinal que representa las operaciones de un constitucionalista ideal ${ }^{26}$. Aquí solo usaré el modelo doctrinal, porque analizo la actividad de los juristas. De acuerdo a este modelo las operaciones que realiza la doctrina pueden ser representadas en tres fases principales: 1) La identificación del texto constitucional, 2) La identificación de las normas constitucionales y 3) La sistematización de las normas constitucionales.

La primera fase consiste en "atribuir sentido o valor a un conjunto de enunciados conforme sobre la base de convenciones sociales ${ }^{\prime 27}$. Su resultado es generalmente pacífico y consiste en "delimitar el conjunto de disposiciones constitucionales (la base enunciativa constitucional) que constituirá el objeto de operaciones de interpretación textual y meta-textual en la segunda fase $e^{\prime 28}$. La segunda fase, en cambio, "es una operación compleja, llevada a cabo sobre la base de un código hermenéutico seleccionado por el intérprete" 29 .

Un código hermenéutico o interpretativo es un conjunto discreto de directivas hermenéuticas que están niveladas en planos lógicamente distin$\operatorname{tos}^{30}$. Chiassoni distingue tres niveles de directivas: primarias, secundarias y axiomáticas. Las directivas primarias "determinan los recursos ${ }^{31}$ dotados de una inmediata eficiencia hermenéutica para atribuir un significado determinado a una disposición traduciéndola en una o más normas explícitas [...] y/o para acreditar la atribución de un significado determinado a una disposición; considerada la doble función, heurística ex ante y justificatoria ex post, de

${ }^{25}$ De acuerdo a Alejandro Calzetta, este modelo es una adaptación de Normative Systems.

${ }^{26}$ El autor añade a estos dos modelos un tercero que no analiza: el modelo de interpretación operativa de la constitución por parte de los jueces comunes. ChIASSONI (2011), p. 182.

27 Chiassoni (2011), p. 187.

${ }^{28}$ Chiassoni (2011), p. 187.

${ }^{29}$ Chiassoni (2011), p. 188.

${ }^{30}$ Las directivas hermenéuticas son también Ilamadas cánones interpretativos, principios interpretativos, técnicas interpretativas, métodos interpretativos, entre otras denominaciones. CHIASSONI (2011), p. 89.

31 Según el mismo autor, "los recursos son datos reales o hipotéticos, concernientes a aspectos jurídicos o extrajurídicos, como usos lingüísticos, líneas de política legislativa, opiniones de expertos, doctrinas ético-políticas, la configuración de fenómenos naturales o sociales, etc.". CHIASSONI (2011), pp. 89-90. 
las propias directivas ${ }^{\prime 32}$. Según Chiassoni son directivas de este tipo las de interpretación lingüística, (seudo)psicológica, autoritativa, teleológica y la heterónoma ${ }^{33}$.

Las directivas hermenéuticas secundarias se refieren a las primarias. Ellas "regulan el uso de las directivas primarias y establecen los criterios para evaluar la corrección total -o habida cuenta de todo- de las interpretaciones producto obtenidas sobre la base de éstas ${ }^{\prime 34}$. Este nivel agrupa directivas de tres tipos diversos: selectivas, procedimentales y preferenciales.

Las directivas axiomáticas son el sustento del código hermenéutico. Ellas "constituyen el conjunto (la base) de principios últimos -de axiomas-de un código hermenéutico, y consisten habitualmente en reglas finales, que prescriben qué objetivo (normalmente general) de política del derecho debe ser perseguido al interpretar las disposiciones [...] en las prácticas interpretativas y en el sentido común de los juristas [...], las directivas axiomáticas no son consideradas como el resultado de elecciones arbitrarias por parte de los intérpretes, sino que son presentadas y defendidas como directivas impuestas, aunque tácitamente, por la naturaleza misma del sistema constitucional positivo en el que se opera" ${ }^{\prime \prime 35}$. Es importante considerar que estas directivas, según el autor, "reflejan las posiciones axiológicas más fundamentales de los intérpretes acerca del modo correcto de interpretar las disposiciones (todas, algunas, etc.) de un ordenamiento positivo" ${ }^{\prime 36}$. Chiassoni ejemplifica estas directivas formulando cuatro códigos hermenéuticos diferentes: códigos naturalistas, estáticos, dinámicos y eclécticos ${ }^{37}$.

En la segunda fase, aunque Chiassoni no lo dice expresamente, creo que el código hermenéutico es función de uno de los cuatro modelos de Constitución postulados por Comanducci que he descrito más arriba. Cualquiera sea el modelo elegido, el código interpretativo siempre "incorporará una concepción ideológicamente comprometida acerca del valor y/o función de la constitución en el ordenamiento positivo ${ }^{138}$. En este sentido, el jurista debe decidir por alguna de las concepciones de Constitución

\footnotetext{
32 Chiassoni (2011), p. 89.

33 ChIASSONI (2011), p. 90.

34 Chiassoni (2011), p. 111.

35 Chiassoni (2011), p. 134.

36 Chiassoni (2011), p. 133.

37 Chiassoni (2011), p. 135.

38 Chiassoni (2011), p. 188. Chiassoni cita a Gianformaggio (1985), pp. 65 y ss.
} 
que están en boga en su comunidad jurídica al momento de fijar su posición doctrinal. Chiassoni distingue dos concepciones de Constitución: la democrático-mayoritaria y la liberal-social ${ }^{39}$.

La Constitución-norma es el resultado de estas operaciones. Según Chiassoni, esta Constitución es "un acervo de normas constitucionales, explícitas e implícitas, que incluye normas de conducta, preceptos de optimización, normas programáticas, así como metanormas sobre la resolución de conflictos entre principios y metanormas relativas a la identificación e integración de las lagunas constitucionales. Dicho acervo de normas será además diacrónicamente mutable: sobre todo siempre que el intérprete acepte una concepción evolutiva de la interpretación textual"40.

La tercera fase es la construcción del sistema constitucional y comporta el paso de la Constitución-norma (master-constitution) a la Constitución-sistema (system constitution). El sistema normativo está compuesto: "a) de un conjunto, relativamente circunscrito y coherente, de principios y de reglas constitucionales; b) de un conjunto de reglas definitorias de los términos técnicos que figuran en las formulaciones de los principios y de las reglas constitucionales; así como, c) de un conjunto de reglas de transformación (concretización) de los principios constitucionales en normas de desarrollo, con vistas a las exigencias prácticas que deban en cada ocasión ser satisfechas"41.

c) Categorías (re)construidas a partir de ideas fragmentarias de la Escuela Genovesa. No he sido capaz de encontrar definiciones claras de las nociones de ideología jurídica, política del derecho y de conceptos teórico-dogmáticos dentro del corpus genovés de primera (Tarello) y segunda generación (Guastini, Barberis y Comanducci). Procedo a definir estas nociones a partir de literatura genovesa heterogénea y de autores de tercera generación, como Núñez ${ }^{42}$.

Una filosofía política es una concepción sobre los fines y funciones del derecho positivo ${ }^{43}$. También responde cuál es el valor y la función política de cada fuente del derecho. La concepción está formada por un conjunto de

${ }^{39}$ Chiassoni (2011), p. 188. Es dudoso si estas concepciones son las principales en Chile durante la década de los noventa.

${ }^{40}$ Chiassoni (2011), p. 189.

${ }^{41}$ Chiassoni señala que solo algún intérprete superviviente o un jurista indómito admirador de las fatigas de Sísifo estará dispuesto a llevar a cabo. ChIASSONI (2011), p. 189.

${ }^{42}$ Sobre este punto es necesario profundizar. No es posible en este artículo. Por todos, ver Núñez (2012).

${ }^{43}$ Este concepto no hace referencia a la disciplina jurídica homónima. Es una noción de inspiración tarelliana que responde a la pregunta sobre el propósito sociocultural que "debería" cumplir el derecho. TARello (2002a); TARello (2002b). 
creencias que responden a la pregunta para qué debe ser usado el derecho. Al menos en una ocasión Tarello usa la expresión política cultural para referirse a este punto ${ }^{44}$. De este modo, la filosofía política está integrada, entre otros elementos, por las elecciones éticas y/o morales que son usadas por el jurista para fijar el rango de significado de los conceptos teórico-dogmáticos y para modular la elección y el modo de uso de las técnicas de interpretación, entre otras decisiones operativas ${ }^{45}$. Son ejemplos de filosofías políticas el neoliberalismo, el utilitarismo, el socialismo, el conservadurismo y el catolicismo.

Una ideología jurídica es una concepción sobre el funcionamiento del derecho positivo ${ }^{46}$. La ideología contiene respuestas sobre las relaciones entre las fuentes formales y sobre el uso del derecho a casos particulares. Una ideología puede contener ideas como las siguientes: "es derecho sólo aquello creado por el legislador", "el juez no debe añadir nada a la voluntad del legislador", "la ley es expresión de la voluntad de legisladores históricos", entre otras ${ }^{47}$.

La política del derecho es el conjunto de ideas, opiniones o doctrinas jurídicas que fundan decisiones operativas sobre las relaciones entre las fuentes del derecho ${ }^{48}$. Estas decisiones están determinadas por la filosofía política y la ideología jurídica y sustentan tesis políticas del tipo: "el derecho civil es (o debe ser supletorio) a todo el sistema jurídico" o "es necesario contar con un subsistema jurídico que regule la administración". En términos generales, estas ideas políticas sustentan confusiones muy difundidas en la dogmática, como la identificación total entre Derecho Administrativo y Derecho Público y/o la de Derecho Civil con derecho común.

Los conceptos teórico-dogmáticos son las categorías usadas por los juristas para interpretar los textos normativos y/o sistematizar porciones del derecho

\footnotetext{
${ }_{44}$ Señala el autor: "Como se desprende del texto, y como intento establecer aquí, utilizado el vocablo ideología en un sentido muy amplio, para indicar filosofías, teorías, complejos doctrinales, en cuanto considerados en su función de instrumentos de políticas culturales en general y de políticas del derecho en especial. Las filosofías, teorías y doctrinas, que mencionaré en seguida, vendrán mencionadas como ideologías en cuanto no serán objeto de consideración sobre sus fundamentos epistemológicos sino sólo en relación con sus implicaciones sociopolíticas y con sus usos políticojurídicos". TARello (2002e), p. 44, nota 2.

45 Aquí incluyo también las concepciones sobre las disciplinas jurídicas en tanto que ellas son discursos prescriptivos sobre qué debería ser el objeto de estudio y el método de ellas.

46 BARBERIS (1987).

47 Ejemplos extraídos de TARello (2002c), pp. 91-93.

${ }^{48}$ Tarello (2002d), p. 283.
} 
vigente ${ }^{49}$. Ellos forman un continuum según su grado de abstracción, generalidad y dependencia de los textos normativos. Son teóricos los conceptos más abstractos y desapegados del lenguaje de las fuentes. Son dogmáticos los conceptos más dependientes de las fuentes. Ambos tipos de conceptos forman complejas estructuras de pensamiento jurídico que funcionan como armazones, estructuras o esquemas conceptuales que podemos llamar estipulativamente "teorías generales" o "dogmáticas" según su ubicación en el continuum $^{50}$. Las teorías generales son esquemas conceptuales formulados en un metalenguaje relativo al discurso de jueces y juristas. Las teorías dogmáticas son, en cambio, esquemas de origen doctrinal y/o judicial sobre el lenguaje de las fuentes. Ellas son usadas para integrar diversos modos de pensar (e interpretar) el derecho positivo. Las teorías interactúan unas con otras y entre sí para integrarse con el lenguaje de las fuentes. Entonces, ellas siempre operan dentro una cultura jurídica espacial y temporalmente determinada ${ }^{51}$.

\section{Proceso de identificación de las categorías}

Las categorías genovesas expuestas permiten hacer un ejercicio de ingeniería inversa sobre los textos dogmáticos. A partir del texto dogmático (entendido como un producto) se descomponen sus piezas para estudiar su funcionamiento. Este trabajo no ha sido desarrollado por los autores genoveses de segunda generación e implica preguntarse cómo los juristas atribuyeron un significado a las disposiciones normativas. Además, exige saber cuál fue el código hermenéutico usado e identificar la política del derecho a la cual ese código se orienta. Cabe advertir que las respuestas a estas preguntas no tienen por qué ser siempre coherentes, completas o siquiera racionales ${ }^{52}$, ya que es posible imaginar que una posición dogmática esté orientada solo por un criterio de conveniencia ad hoc, ya sea individual o institucional ${ }^{53}$.

\footnotetext{
49 Nociones como "derecho subjetivo", "constitución", "nulidad", "validez", "república", "principio" y "estado de derecho" son conceptos de este tipo. El listado hace evidente que los conceptos pueden jerarquizarse usando criterios variados, uno de los cuales es el grado de abstracción y generalidad de su rango de significación. Un segundo criterio es el grado de dependencia que tiene el concepto con la interpretación de cierta disposición normativa.

50 Para profundizar sobre este punto, ver NúÑ̃z (2016).

51 Tarello (2002c), p. 96. Ver también Tarello (1975), Tarello (1976a), Tarello (1976b). La tesis del continuum implica rechazar la posibilidad de una tipología de conceptos teórico-dogmáticos y, correlativamente, de las teorías generales y de las teorías dogmáticas.

${ }^{52}$ Uso la expresión "racional" en el sentido de estándar procedimental.

53 Chiassoni (2011), p. 88.
} 
El primer paso es explicitar que el producto del proceso de interpretación doctrinal es el resultado interpretativo adscrito a la disposición. Este resultado es la norma jurídica que el jurista le atribuyó al texto normativo. La cuestión de qué norma o normas son atribuidas a una disposición depende de una combinación de conceptos teórico-dogmáticos y del código hermenéutico usado $^{54}$. El segundo paso consiste en identificar el modelo de Constitución que se expresa en el discurso dogmático analizado. En los casos en que ello no sea explícito es necesario formular un juicio atributivo. Para ello, hay que formular conjeturas sobre la política del derecho, la ideología jurídica y la filosofía política normativa que defiende la posición dogmática analizada. Ello es así, porque los modelos de Constitución están determinados por decisiones y preferencias del jurista sobre cuál es la (supuesta) finalidad del ordenamiento positivo y su relación con otros propósitos sociales ${ }^{55}$.

El tercer paso requiere contrastar las conjeturas sobre el modelo de Constitución y la política del derecho, la ideología jurídica y la filosofía política normativa que defiende la posición dogmática analizada. Observar el grado de ajuste que ellas tienen con el código hermenéutico utilizado y luego comparar los resultados con los datos provenientes de posiciones rivales o de textos dogmáticos elaborados desde otras disciplinas o sobre asuntos parcialmente diferentes.

\section{Análisis del modo de interpretar la Constitución de Mario Bernaschina}

El análisis lo he dividido en dos partes. La primera busca exponer los argumentos sin enjuiciarlos. La segunda parte se aboca a la identificación de las categorías genovesas que es posible identificar a partir del texto analizado.

\subsection{Exposición ${ }^{56}$}

En su artículo de 1949, Bernaschina dice bastante, a pesar de su brevedad. Reproduzco con detalle sus ideas en el mismo orden en que están en

\footnotetext{
${ }^{54}$ A su vez, al analizar los conceptos teórico-dogmáticos usados y el código hermenéutico respectivo es necesario considerar que ellos son la instanciación de decisiones y preferencias del intérprete sobre el modelo de constitución y también sobre la política del derecho, la ideología jurídica y la filosofía política que orientan el trabajo.

55 Otros signos que permiten atribuir un modelo de constitución a un discurso dogmático son los conceptos teórico-dogmáticos y las técnicas de interpretación usadas por el jurista. Explico esto en los siguientes párrafos.

${ }^{56}$ Este análisis tiene un formato diferente a los posteriores en razón de la dificultad que existe en recuperar la obra de Bernaschina desde las bibliotecas.
} 
el texto, porque me parece útil fijar la originalidad de su posición sobre la NDP para luego juzgar los trabajos de quienes le sucedieron. Además, se trata de un texto corrientemente citado, pero muy difícil de encontrar. Uso los mismos subtítulos que el texto analizado para mayor claridad del lector.

a) Generalidades. En este apartado el autor fija como punto de inicio la ausencia de precisión del concepto de nulidades de derecho público o nulidades administrativas en relación con la Teoría General del Estado. Señala que la Corte Suprema "se ha alejado del texto claro y terminante de ciertas disposiciones constitucionales" ${ }^{\prime \prime}$. Luego, establece como su propósito distinguir el concepto de nulidad propio del derecho público del concepto de nulidad de derecho privado.

A continuación, señala que los órganos del Estado tienen una competencia limitada, regulada por el propio ordenamiento. Estas limitaciones impiden que las personas que se desempeñan como titulares o miembros de los órganos del Estado no puedan comprometerse libremente, porque sus decisiones no van a crear actos jurídicos personales, sino que crean normas estatales. Así, la constitución fija "la competencia general de los órganos estatales y la acción de los funcionarios [...] sólo pueden realizar aquellos actos para los cuales están expresamente facultados como lo reconoce el artículo $4^{\circ}$ de la Constitución" ${ }^{\prime \prime 5}$. Si los órganos estatales exceden su competencia no pueden vincular al Estado y se generan dos situaciones distintas: a) Los funcionarios titulares que han actuado fuera de la competencia se hacen responsables de las penas y sanciones que el ordenamiento jurídico fija y b) El acto es nulo, no puede considerarse como un acto estatal ${ }^{59}$.

b) Nulidad relativa y nulidad absoluta. Este apartado trata la doctrina civil de las nulidades (absoluta y relativa). Cita el artículo 1682 del Código Civil para sostener que el principal efecto de la nulidad declarada por los tribunales es la restitución de las partes al estado anterior a la realización

57 Bernaschina (1949), p. 550.

58 Bernaschina (1949), p. 548.

${ }_{59}$ Para ello usa: una Teoría del Estado cercana a Kelsen (a quien cita en algunas ocasiones en su Manual de Derecho Constitucional publicado años después); una noción de competencia como límite a la autonomía; una noción de validez del acto administrativo como cadena de imputación al sistema normativo superior y una noción de Constitución como "ordenamiento jurídico superior". Dice al efecto: "[...] los órganos del Estado tienen una competencia limitada, regulada por el propio ordenamiento jurídico, desde el momento en que sólo las personas pueden querer o manifestar su voluntad en forma libre. Las personas naturales que se desempeñan como titulares o miembros de los órganos estatales no pueden comprometerse libremente, porque sus decisiones no van a crear actos jurídicos personales, sino que van a crear normas estatales, actos jurídicos imputables al órgano mismo y, en definitiva, al Estado". Bernaschina (1949), p. 548. 
del acto nulo. Cita a Kelsen diciendo que esta es una anulabilidad pro praeterito $^{60}$. Después señala que el acto debe ser cumplido mientras la nulidad no sea declarada y que no existen diferencias sustanciales en los efectos de la nulidad relativa y absoluta. Solo las causales y los plazos en que puede sanearse el vicio son diferentes ${ }^{61}$.

c) La nulidad absoluta en derecho público. Inicia este apartado señalando que la nulidad absoluta y relativa producen los mismos efectos una vez declaradas por la autoridad judicial. Cita el artículo 1683 del Código Civil para señalar que la nulidad absoluta puede ser declarada de oficio. Para Bernaschina, "el hecho de que los jueces estén facultados para declarar de oficio la nulidad absoluta ha permitido la aplicación de esta especie de nulidad a las infracciones a las leyes de Derecho público. Por otra parte, el artículo 1462 del Código Civil prescribe que hay objeto ilícito en todo lo que contraviene el derecho público chileno" ${ }^{\prime \prime 2}$. Para el autor, "los actos emanados de un órgano que actúa fuera de su competencia pueden considerarse incluidos en esta causal de nulidad absoluta, en relación al artículo $4^{\circ}$ de la Constitución" ${ }^{\prime \prime 63}$. Para entender los alcances de estas afirmaciones es necesario tener en consideración la dogmática civil sobre la nulidad y el objeto ${ }^{64}$. Más adelante trato este punto.

Acto seguido, critica las decisiones de la Corte Suprema y apoya (con reservas) algunas decisiones de la Contraloría General de la República. Las decisiones de la Corte que el autor critica son dos: la de 15 de diciembre de $1922^{65}$ y la de 24 de septiembre de $1943^{66}$. A la primera la cuestiona porque usa el criterio del artículo 1683 del Código Civil (la nulidad puede y debe ser declarada por el juez, aun sin petición de parte, siempre que aparezca de manifiesto en el acto o contrato) para anular una concesión de aguas

60 Bernaschina (1949), p. 549.

61 Este punto es interesante en la medida en que el autor acepta la tesis dogmática que afirma que el plazo para alegar la nulidad es un plazo de saneamiento del vicio en lugar que un plazo de caducidad de la acción.

62 Bernaschina (1949), p. 550.

63 Bernaschina (1949), p. 550.

${ }^{64}$ La idea de que los actos y contratos civiles que infringen el Derecho Público padecen de objeto ilícito ya está en las obras de VeLASCO (1941) y de AlESSANDRI (1949). Resta investigar los detalles de las posiciones dogmáticas sobre el alcance del debate sobre la nulidad en las obras de derecho civil chileno contemporáneas a Bernaschina.

65 Gaceta de los Tribunales (1922), p. 379.

66 Revista de Derecho y Jurisprudencia (1944), p. 228. 
territoriales emanada de una autoridad sin facultades ${ }^{67}$. De esta sentencia Bernaschina solo cree que acierta en considerar que la nulidad es independiente del recurso de anulabilidad ${ }^{68}$. A la segunda sentencia la critica porque condiciona la nulidad a la declaración de ilegalidad, porque restringe los efectos de la nulidad con posterioridad a la declaración y porque señala que la declaración de nulidad "no acarrea la nulidad de los efectos producidos durante el tiempo anterior a la declaración de ilegalidad, pues durante ese tiempo el acto público administrativo ha debido reputarse como válido" ${ }^{\prime \prime}$.

Bernaschina analiza seis dictámenes de la Contraloría General de la República. Critica el dictamen No 23.778, de 27 de junio de 1938, porque afirma que las delegaciones de atribuciones que hacían las municipalidades sin autorización expresa del legislador padecían de nulidad absoluta ${ }^{70}$.

d) Las nulidades administrativas o de derecho público. La diferenciación de las nulidades de Derecho Público de las nulidades de Derecho Privado radica en dos rasgos: las partes no pueden ratificar el vicio y este no se sanea por el transcurso del tiempo, "pues el acto nulo no puede producir efecto alguno como acto jurídico estatal desde el momento en que no puede ser imputable al Estado, como ordenamiento jurídico, porque ha sido dictado fuera de ese ordenamiento con infracción de las normas jurídicas [...] no es necesario que ella sea declarada por la autoridad, salvo las excepciones expresas que la ley establece, de manera que antes y después de su declaración, si es que procede y se hace, el acto no puede producir efecto alguno [... $]^{\prime 71}$. Justifica esta conclusión en la interpretación de los artículos 4ㅇ, 23 y 75 de la Constitución.

\footnotetext{
67 Bernaschina (1949), p. 550.

${ }^{68}$ Bernaschina (1949), p. 555.

69 Bernaschina (1949), pp. 553-558.

70 Apoya, en cambio, el dictamen $N^{\circ}$ 6.687, de 10 de febrero de 1948, y el dictamen $N^{0} 13.915$, de 19 de abril de 1948, que aceptan la nulidad de pleno derecho. Se muestra de acuerdo con el dictamen $N^{\circ} 45.915$, de 15 de noviembre de 1949, que ordena hacer una nueva publicación de un proyecto de ley insertado en el Diario Oficial por omisión de todos los trámites constitucionales y legales. También apoya el dictamen $\mathrm{N}^{\circ}$ 17.270, de 2 de junio de 1950, porque se funda en la idea de que el acto nulo acarrea la nulidad de los actos derivados de él. Finalmente, considera que el primer dictamen que plantea y que reconoce claramente la diferencia total y esencial que existe entre las nulidades civiles y las nulidades administrativas es el dictamen $N^{0}$ 11.770, de 6 de abril de 1950. Bernaschina hace una cita textual del siguiente fragmento del dictamen: "El acuerdo adoptado por la Corporación en contravención a ese artículo (58 del Estatuto de Empleados Municipales) es nulo, y no puede producir efecto jurídico alguno, por tratarse de una nulidad de derecho público que no necesita de declaración de autoridad alguna. La nulidad se ha producido en el momento mismo en que se ha aprobado el acuerdo contrario a la ley". BernasCHINA (1949), p. 554.
}

71 Bernaschina (1949), p. 551. 
La principal técnica de interpretación usada por el autor para establecer una concordancia entre los artículos $4^{\circ}$ y 23 de la Constitución es la literal. Así, el autor interpreta la última frase del artículo $4^{\circ}$ (Todo acto en contravención a este artículo es nulo) y la última frase del artículo 23 (es nula de derecho y no puede producir efecto alguno) como aludiendo a la misma noción de nulidad. En la sección siguiente analizo este punto con detalle.

e) La nulidad procesal y la inconstitucionalidad de las leyes. Según el autor, las reglas de las nulidades de Derecho Público no son aplicables a las decisiones de los tribunales, a pesar de que crean actos estatales y que sus resoluciones son imputables al Estado. Básicamente, señala dos razones. Primero, porque se opondría al imperio y a la independencia total de la judicatura. Segundo, porque existen reglas especiales que dan lugar a la nulidad procesal como nulidad especial ${ }^{72}$. Así, el Código Orgánico de Tribunales equipara, según el autor, esta nulidad con las nulidades civiles ${ }^{73}$. Esta nulidad tampoco es posible tratándose de actos del Poder Legislativo, porque para ello está el recurso de inconstitucionalidad o de inaplicabilidad de las leyes ${ }^{74}$.

f) Jurisprudencia de la Corte Suprema. Bernaschina cita dos sentencias de la Corte Suprema. Una sentencia de 1922 (de la cual no hay referencias bibliográficas) que señala que la nulidad del artículo 151 de la Constitución de 1833 ( $4^{\circ}$ de la Constitución de 1925) es nulidad absoluta. La segunda sentencia es del año $1943^{75}$. Sobre la primera sentencia el autor dice que sigue un "criterio civilista". Sobre la segunda, el autor dice que tiene "resabios de Derecho privado", pues condiciona la nulidad a la declaración de ilegalidad y restringe los efectos de la nulidad al tiempo posterior a la declaración ${ }^{76}$.

g) Evolución de la jurisprudencia de la Contraloría General de la República. Aquí señala que el organismo contralor en el dictamen $N^{\circ} 23.778$ sigue la

\footnotetext{
72 Aquí el autor usa una versión del argumento lex specialis.

73 Bernaschina (1949), p. 552.

74 "El primero produce efectos generales, la ley queda derogada, sin perjuicio de la validez de los actos ejecutados en el tiempo anterior a esta declaración: en virtud del recurso de inaplicabilidad, la ley se declara inaplicable para un juicio determinado y solamente se suspende su vigencia para ese caso particular, tal como lo establece el artículo 86, inciso $2^{\circ}$, de la Constitución de 1925". BernasChina (1949), p. 552. Esta es otra versión del argumento lex specialis.

${ }^{75}$ Revista de Derecho y Jurisprudencia, (1944), p. 228.

${ }^{76}$ La sentencia citada por Bernaschina dice: "En materia administrativa la nulidad de un acto declarado ilegal no opera retroactivamente como en el Derecho Civil; en el orden administrativo la declaración de ilegalidad de un acto no acarrea la nulidad de los efectos producidos durante el tiempo anterior a la declaración de ilegalidad, pues durante ese tiempo el acto público administrativo se reputa válido y debe cumplirse como tal dentro del principio de la ejecutoriedad de los actos del poder público".
} 
teoría clásica que equipara las nulidades de Derecho Público a la nulidad absoluta civil. Después indica que el dictamen $\mathrm{N}^{0} 32.829$, de 21 de septiembre de 1944, comete los mismos errores que la sentencia de la Corte Suprema del año 1943 (que exige la declaración judicial para la nulidad). Luego, el autor expresa que el dictamen $N^{\circ}$ 6.687, de 10 de febrero de 1948, acepta la nulidad de pleno derecho y que el dictamen $\mathrm{N}^{0} 13.915$, del 19 de abril de 1948, dispone expresamente que la nulidad administrativa opera de pleno derecho ${ }^{77}$.

A continuación, sostiene el autor que el dictamen $N^{\circ}$ 45.915, de 15 de noviembre de 1949, aunque no indica claramente los efectos de las nulidades administrativas, recoge la nulidad de pleno derecho. Por último, argumenta que el dictamen $N^{\circ} 11.770$, de 6 de abril de 1950, reconoce definitivamente la teoría de las nulidades de derecho público diciendo: "El acuerdo adoptado por la Corporación en contravención a ese artículo (58 del Estatuto de Empleados Municipales) es nulo, y no puede producir efecto jurídico alguno, por tratarse de una nulidad de derecho público que no necesita declaración de autoridad alguna. La nulidad se ha producido en el momento mismo en que se ha aprobado el acuerdo contrario a la ley"78.

h) Ilegalidad o anulabilidad y nulidad. Bernaschina indica que es un rasgo común a estas nociones la existencia de una norma dictada fuera de la competencia de un órgano. Señala que los conceptos de nulidad y anulabilidad o ilegalidad se diferencian. La ilegalidad presupone declaración posterior para que sea reconocida. En cambio, "la nulidad es el efecto de un acto realizado fuera de la competencia estatal, no es necesario solicitar declaración, el acto carece de valor jurídico" ${ }^{\prime 79}$. Para Bernaschina son ejemplos de anulabilidad o ilegalidad la nulidad procesal y la inconstitucionalidad. Aunque en "estricta doctrina, el acto inconstitucional debería ser nulo y no tener valor alguno ${ }^{\prime \prime 80}$, la misma constitución señala un efecto diferente a esta infracción desde que fija un tribunal especial para alegar el vicio ${ }^{81}$. Más abajo continúa diciendo: "Las normas administrativas atacadas de vicio de nulidad

\footnotetext{
77 El dictamen citado dice: "El efecto de la ilegalidad de un contrato municipal celebrado con infracción de disposiciones expresas, es la nulidad, que opera por el solo ministerio de la ley, sin que se requiera la declaración de tribunal ni autoridad alguna. La Municipalidad respectiva, por esta razón, no está obligada a cumplir el contrato". BernaSCHINA (1949), p. 554.

${ }^{78}$ Bernaschina (1949), p. 554. Según el autor este es el primer dictamen que reconoce claramente la diferencia total y esencial que existe entre las nulidades civiles y las nulidades administrativas.

79 Bernaschina (1949), p. 554.

80 Bernaschina (1949), p. 554.

81 Aquí el autor usa otra versión del argumento lex specialis.
} 
son nulas por regla general; por excepción opera en ellas la anulabilidad, sin que, por su parte, impida negarle todo valor al acto dictado fuera de la competencia de los órganos administrativos" ${ }^{\prime \prime 2}$.

Finaliza esta sección argumentando que: i) La Corte Suprema ha sostenido que la nulidad es independiente del recurso de anulabilidad ${ }^{83}$; ii) La Contraloría ha sostenido que la nulidad y la ilegalidad pueden coexistir simultáneamente y que el perjudicado puede optar por perder a la autoridad que declare la ilegalidad o solicitar a la Contraloría que se abstenga de aplicar la norma nula y que le desconozca todo valor administrativo" ${ }^{84}$; iii) La Contraloría ha sostenido que un acto cuya anulabilidad no se podría pedir por el transcurso del plazo puede desconocerse como nulo (ilegalidad y nulidad pueden hacerse valer de forma simultánea o sucesiva); iv) Rechaza la idea de que el recurso de ilegalidad (al que considera excepcional) fijado por la ley condicione la validez del acto a la declaración de la autoridad que se pronuncia sobre ese recurso, ya que por lex superior, la ley no puede modificar los efectos que señalan los artículos 4ㅇ, 23 y 75 de la Constitución, y v) En casos especiales "en donde la Constitución prohíbe a las autoridades negarse a obedecer una orden para el pretexto que es nula, no cabe aplicar la teoría de las nulidades administrativas, lo mismo, en el caso en que la Constitución prescriba una sanción o efecto distinto para el acto emanado de una autoridad incompetente ${ }^{1 / 85}$.

i) Características de las nulidades administrativas. El autor advierte un uso indistinto de las expresiones "nulidades de Derecho público" y "nulidades administrativas". Para aclarar el panorama señala que las primeras son un género y las segundas la especie. Descartada la aplicación de la nulidad de derecho público a las decisiones judiciales (recurribles por nulidad procesal) y a los actos del legislador (recurribles por inconstitucionalidad o inaplicabilidad) queda su aplicación a los actos administrativos, en contra de los cuales, según el autor, también puede recurrirse por ilegalidad en casos expresamente fijados por la $l e y^{86}$. La principal característica de la teoría de las nulidades de derecho público es su relatividad ${ }^{87}$, porque solamente pueden aplicarse

\footnotetext{
82 Bernaschina (1949), p. 555.

${ }^{83}$ Cita la sentencia de 15 de diciembre de 1922, publicada en Gaceta de los Tribunales, segundo semestre, sentencia $N^{\circ} 81$, p. 379.

${ }^{84}$ Cita el dictamen No 17.270, de 2 de junio de 1950. Bernaschina (1949), p. 554.

${ }^{85}$ Bernaschina (1949), p. 556.

86 Bernaschina (1949), p. 556.

${ }^{87}$ Este adjetivo no se relaciona con la nulidad relativa civil. La clasificación de Bernaschina, en este punto, se separa de los criterios civiles.
} 
a actos administrativos y por ello su nombre "se convierte, de acuerdo a las normas positivas, en una teoría de las nulidades administrativas" ${ }^{\prime \prime 8}$.

j) La nulidad administrativa opera de pleno derecho. Esta es la segunda cualidad de esta teoría de las nulidades administrativas. Bernaschina señala que "no se necesita pedir su declaración ante autoridad alguna; basta con que el particular afectado o el órgano que deba cumplirlo desconozca sus efectos" ${ }^{\prime \prime 8}$. Después sostiene que la Contraloría ha actuado correctamente no declarando la nulidad, se limita a comprobar la nulidad y opera prescindiendo del acto nulo.

Sin embargo, más abajo, el autor señala que se trata de una conclusión meramente doctrinaria ${ }^{90}$. La razón la expresa diciendo que "en el hecho la autoridad administrativa tratará de hacer valer el acto contrario a la ley por medio de coacción, desde el momento en que tiene a su disposición la fuerza pública que es esencialmente obediente y no puede negarse a cumplir un acto aun cuando su nulidad aparezca de manifiesto's1.

Finaliza este punto señalando que la doctrina contraria llega casi a la misma conclusión. Sostiene que la nulidad necesita ser declarada para que el acto pueda dejar de tener efectos jurídicos y que esta declaración opera con efecto retroactivo, tal como operan las nulidades de Derecho Civil. Así, a criterio del autor, la doctrina del efecto retroactivo solo puede aplicarse cuando se hace uso del recurso de ilegalidad, "cuando la ley de forma expresa, limita el principio general de las nulidades administrativas"92. Esto es así porque "el acto realizado fuera de la competencia no puede imputarse al órgano, pues sólo puede imputarse al Estado, como acto estatal, el que ha sido realizado de acuerdo con las normas jurídicas, dentro de la competencia expresa de los órganos ${ }^{\prime \prime 93}$. Acto seguido, revisa nuevamente la sentencia de 1943, la cual señala que "la declaración de ilegalidad no acarrea la nulidad de los efectos producidos durante el tiempo anterior a la declaración de ilegalidad, pues durante ese tiempo el acto público administrativo ha debido reputarse válido $^{\prime \prime 94}$. Bernaschina discrepa con la Corte e insiste en la idea de que no

\footnotetext{
88 Bernaschina (1949), p. 556.

89 Bernaschina (1949), p. 557.

91 Bernaschina (1949), p. 557.

92 Bernaschina (1949), p. 557.

93 Bernaschina (1949), p. 557.

94 Bernaschina (1949), p. 558.
}

90 Bernaschina parece entender que una posición "meramente doctrinaria" es aquella que puede ser justificada en abstracto sin pensar en su viabilidad práctica. 
cabe hablar de actos administrativos que se reputan válidos, porque solo los actos dictados en forma regular son válidos; "los demás, de acuerdo con el artículo $4^{\circ}$ de la Constitución de 1925, no tienen valor ${ }^{\prime 195}$.

k) La nulidad administrativa produce también la nulidad de los actos derivados del acto nulo. Para mostrar cómo el acto nulo acarrea la nulidad de los actos derivados de él, el autor analiza el dictamen $N^{\circ} 17.270$ de la Contraloría y el artículo 84 del Reglamento del Estatuto de los Empleados Municipales. Señala que no es posible validar los actos directos derivados del acto jurídico nulo, es decir, los actos que se refieran a la integración de los órganos estatales, sin perjuicio de que los actos de gestión realizados por un funcionario indebidamente nombrado se presuman válidos respecto de terceros de buena $\mathrm{fe}^{96}$.

\subsection{Análisis}

La filosofía política y la ideología jurídica de Bernaschina no son fáciles de determinar usando exclusivamente el texto de 1949. Sin embargo, en razón de trabajos anteriores y posteriores del mismo autor es posible sostener que su posición es liberal ${ }^{97}$. Su ideología jurídica es positivista y parece sustentar una política del derecho orientada hacia el derecho público, en términos de disociar el uso de la nulidad absoluta civil para sancionar la ilegalidad de actos administrativos. Sin embargo, este juicio puede ser balanceado en razón del uso de categorías dogmáticas civiles y en relación con la construcción de una analogía parcial entre la ilegalidad del acto administrativo y la inexistencia civil. Asi se justifica la posibilidad de desconocer y resistir el acto nulo. Estas decisiones se expresan en un modelo descriptivo de constitución como norma. Con todo, usando la información precedente, es posible afirmar que los conceptos teóricos explícitos son: producción de efectos (eficacia) y obligatoriedad. Mientras que los implícitos son competencia, nulidad y validez. Los conceptos dogmáticos son categorías propias del Derecho Civil como la nulidad absoluta.

Es importante resaltar que el trabajo de Bernaschina busca justificar una interpretación correctora de las disposiciones normativas disponibles. Esta

95 Bernaschina (1949), p. 558.

96 Bernaschina (1949), pp. 558-559.

${ }_{97}$ El liberalismo está presente en la idea de resguardar al ciudadano frente a la administración. Sin embargo, este juicio puede moderarse con uno de los presupuestos que el autor acepta y no discute. Por ejemplo, la ausencia de crítica a la inexistencia de tribunales contencioso-administrativos implica aceptar que es necesario que tribunales especiales juzguen a la administración y, entonces, concederle un estatus de privilegio frente al ciudadano. 
interpretación se aleja de la literal, porque no se apoya en el sentido corriente que tienen las expresiones usadas por el constituyente ${ }^{98}$. En ese orden de ideas, los argumentos interpretativos ${ }^{99}$ usados por el autor para interpretar la constitución son los siguientes.

Las técnicas de interpretación textual usadas por el autor son aquellas directivas que permiten justificar la triple concordancia entre los artículos $4^{\circ}$, 23 y 75 de la Constitución de 1925 como fundamento constitucional de la NDP. Aunque el foco del análisis es la interpretación de la Carta Fundamental, es indispensable hacer referencias a argumentos de la dogmática civil que parecen funcionar como un telón de fondo de la labor interpretativa. Es necesario aclarar que el autor no es suficientemente explícito para fundar su trabajo y, por ello, lo que sigue es un conjunto de conjeturas sobre el trabajo de Bernaschina.

\subsubsection{Directivas primarias}

La argumentación se desarrolla de acuerdo a las siguientes directivas primarias de interpretación:

c.1.) DP-5: "A las disposiciones se les debe atribuir el significado que resulte del uso especializado de las palabras y de las reglas gramaticales de la lengua natural en la que está formulada, en el momento de la aplicación de la disposición"100.

c.2.) DP-15: "A una disposición se le debe atribuir el significado correspondiente a los usos lingüísticos del legislador (entendido como una entidad impersonal)"101. Siguiendo a Chiassoni, es necesario destacar cuatro puntos en relación con esta directiva: i) Esta directiva necesita asumir la constancia terminológica del legislador (ello implica que un buen legislador léxico es riguroso terminológicamente, porque ello promueve la certeza de la regulación); ii) Ella es una directiva racionalista en razón de su fundamento y sistemática en relación con su mecánica; iii) La directiva prescribe tener en cuenta las otras disposiciones donde aparecen los mismos términos para atribuir el mismo significado a todas ellas; iv) Está expuesta a la discrecionalidad del intérprete, pues él fija qué otras disposiciones se deben tener

\footnotetext{
98 Guastini (2000).

99 Chiassoni (2011), p. 109, distingue directivas de argumentos y reserva la expresión "directiva" para los enunciados prescriptivos generales y deja la expresión "argumento" para hacer referencia a argumentos-tipo o argumentos-instancia.

100 Chiassoni (2011), p. 92.

101 Chiassoni (2011), p. 100.
} 
en cuenta, cuál es el criterio de identificación de un hábito en el legislador, entre otras decisiones ${ }^{102}$.

Las directivas DP-5 y DP-15 aplicadas como argumentos justifican, en parte, la tesis que dice que los artículos $4^{\circ}, 23^{103}$ y $75^{104}$ de la Constitución de 1925 aluden a la misma noción de nulidad. Observar más de cerca este proceso de justificación puede iluminar las decisiones discrecionales del intérprete.

La expresión "nulo" del artículo $4^{\circ}$ y la expresión "nula" del artículo 23 designan el mismo significado (es decir, se refieren a la misma noción de nulidad). Aunque el autor no es explícito, resulta evidente que, a su juicio, el significado atribuido al lenguaje de las fuentes no es un sentido ordinario, corriente o natural de "nulidad", sino que el significado que atribuyen a esta expresión un grupo de especialistas en dogmática: quienes cultivan el Derecho Civil chileno.

La expresión "es nula de derecho" del artículo 23 es interpretada por Bernaschina como designando una noción de nulidad diferente de la nulidad absoluta del derecho civil. La noción de nulidad del autor se asemeja parcialmente al concepto civil de inexistencia. En este sentido, él hace una interpretación de las disposiciones constitucionales con clara orientación al derecho público, es decir, oponiéndose a la idea que afirma el uso de las nociones de Derecho Civil para interpretar los textos de otro sector del ordenamiento $^{105}$. Para mayor claridad es necesario dar una mirada a las argumentaciones civiles sobre la nulidad.

En el Derecho Civil chileno, según el artículo $1462^{106}$, hay objeto ilícito en todo lo que contraviene el derecho público chileno y, de acuerdo al artículo

102 Chiassoni (2011), p. 100.

103 "Toda resolución que acordare el Presidente de la República, la Cámara de Diputados, el Senado o los Tribunales de Justicia, a presencia o requisición de un ejército, de un jefe al frente de fuerza armada o de alguna reunión del pueblo que, ya sea con armas o sin ellas, desobedeciere a las autoridades, es nula de derecho y no puede producir efecto alguno". La cursiva es nuestra.

104 "Todas las órdenes del Presidente de la República deberán firmarse por el Ministro del departamento respectivo, y no serán obedecidas sin este esencial requisito". La cursiva es nuestra.

105 Desde la Teoría del Derecho hay no menos de dos modos de comprender la argumentación que afirma la posibilidad de usar nociones de Derecho Civil para interpretar casi cualquier disposición normativa. Primero, se puede sostener que los dogmáticos entienden que el Derecho Civil funciona como supletorio en un sentido sustantivo y/o en un sentido interpretativo o metodológico. Segundo, es posible sostener que los dogmáticos entienden que el ordenamiento debe interpretarse de modo sistemático y, entonces, el resultado interpretativo del texto constitucional debe alinearse con las nociones civiles. El vínculo entre el Derecho Civil y el Administrativo es estudiado desde la historia por CASSESE (2014).

106 Art. 1462. Hay un objeto ilícito en todo lo que contraviene al Derecho Público chileno. Así, la promesa de someterse en Chile a una jurisdicción no reconocida por las leyes chilenas es nula por el vicio del objeto. 
1682, ese objeto ilícito es sancionado con nulidad absoluta al igual que la ausencia de requisitos que la ley ordena para el valor del acto o contrato. De ahí que Bernaschina afirme, de modo implícito, que la argumentación estándar sobre la nulidad absoluta civil se aplique por analogía a los artículos 4, 23 y 75 de la Constitución de 1925.

Esquemáticamente, esta argumentación civil dice así: todo acto y contrato que la ley prohíbe es nulo de nulidad absoluta. Esta regla general se desprende de tres disposiciones: 1. Es nulo todo acto que contraviene una ley prohibitiva (art. 10) ${ }^{107} ; 2$. Hay objeto ilícito en todo contrato prohibido por las leyes (art. 1466 parte final) y 3. Todo acto que padece de objeto ilícito es sancionado con nulidad absoluta (art. 1682). Una disposición de refuerzo de la argumentación anterior se encuentra en el artículo 1462, que señala que todo acto que infringe el derecho público chileno padece de objeto ilícito ${ }^{108}$. Este es un argumento de refuerzo, porque la doctrina lo considera un caso de objeto ilícito reglado de modo especial ${ }^{109}$.

107 Art. 10. Los actos que prohíbe la ley son nulos y de ningún valor; salvo en cuanto designe expresamente otro efecto que el de nulidad para el caso de contravención.

Comentando este artículo, LEÓN (1983) señala que "son leyes prohibitivas las que impiden ejecutar un acto sin que sea posible realizarlo en modo alguno, y cuya contravención acarrea nulidad absoluta, salvo que la ley señale otro efecto que el de nulidad para el caso de contravención" (p. 28). A continuación, señala en la misma página que no es frecuente encontrar problemas para precisar este caso de objeto ilícito, puesto que "la ley misma contiene la prohibición, aunque no emplee el verbo prohibir, como sí dice, por ejemplo, 'no es lícito', 'no vale', 'se mirará como no ejecutado', 'no puede estipularse', etc.". Luego dice: "El concepto de orden público inspira las leyes prohibitivas, pero en éstas ya no nos interesa atender al orden público para conocer su sanción, toda vez que habrá objeto ilícito en su contravención por la sola circunstancia de tratarse de un acto prohibido por las leyes". LEÓN (1983), p. 37.

${ }^{108}$ Es necesario notar que esta disposición usa el concepto de "Derecho Público chileno" en lugar de "orden público". Para Alessandri, el concepto de "Derecho Público" engloba al de orden público. Luego, al comentar el artículo $4^{\circ}$ de la Constitución dice: "Constituye una aplicación del principio fundamental de Derecho, según el cual en Derecho Público sólo es lícito hacer lo que expresamente permiten las leyes, y viene a ser una confirmación constitucional del principio establecido en el artículo 1462, porque reafirma, en forma muy explícita, que lo que contraviene al Derecho Público, que es el que señala, como decíamos, las facultades, autoridad o derechos de que están investidos los funcionarios públicos es 'nulo', nulidad que no puede ser otra que la nulidad absoluta". AlesSANDRI (1949), p. 132.

109 LEÓn (1983) analiza este artículo y dice: "El Derecho Público es el que organiza el Estado y fija las atribuciones y competencia de los Poderes Públicos.

"Las leyes de Derecho Público son, generalmente, de orden público y, en consecuencia, su contravención acarreará nulidad absoluta por objeto ilícito, ya que lo hay en todo acto contrario al orden público. Por eso, la mayoría de los actos contrarios al Derecho Público habrían quedado sancionados por tener objeto moralmente imposible por aplicación de la norma general sobre contravenciones al orden público, sin necesidad de esta disposición especial [...] Por otra parte, la Constitución Política 
Es posible arribar a la misma nulidad si se considera que, de acuerdo al artículo 1682, es nulo todo acto que infringe una norma (imperativa) que fija algún requisito o formalidad prescrita para el valor del acto o contrato en consideración de su naturaleza ${ }^{110}$. Es importante resaltar que es tradicional en la doctrina civil chilena sostener no menos de cinco ideas complementarias: a) La interpretación del artículo 1444 del Código Civil ${ }^{111}$ como una distinción entre requisitos de existencia y de validez del acto jurídico ${ }^{112}$; b) La discusión doctrinaria entre inexistencia y nulidad ${ }^{113}$; c) La conceptualización de la nulidad como una sanción y, entonces, la idea que sostiene que la acción de nulidad solo tiene sentido cuando han ocurrido consecuencias fácticas del acto nulo que puedan ser revertidas, porque no hay una acción meramente declarativa de nulidad; d) Toda acción de nulidad conlleva los efectos descritos

establece que toda contravención al Derecho Público es nula absolutamente. El art. $7^{\circ}$ de la Carta dispone al efecto [cita el artículo de la Constitución de 1980] Si la infracción es a la Constitución misma, se aplica también esta sanción de nulidad que señala el art. $7^{\circ}$ citado". León (1983), p. 46.

110 No es obvio que esta idea necesita sostener que la expresión "valor" de los artículos 1681 y 1682 tiene el significado "de presencia o ausencia de un requisito de validez". Esta idea la resalta SAN MARTín (2015), p. 22, quien además discute el significado de una serie de expresiones semejantes en el Código Civil chileno.

111 Art. 1444. Se distinguen en cada contrato las cosas que son de su esencia, las que son de su naturaleza, y las puramente accidentales. Son de la esencia de un contrato aquellas cosas sin las cuales o no produce efecto alguno, o degenera en otro contrato diferente; son de la naturaleza de un contrato las que no siendo esenciales en él, se entienden pertenecerle, sin necesidad de una cláusula especial; y son accidentales a un contrato aquellas que ni esencial ni naturalmente le pertenecen, y que se le agregan por medio de cláusulas especiales.

112 San Martín ha defendido que esta distinción no tiene fundamento en el texto del Código Civil. SAn Martín, (2015).

113 Según San Martín, "En Chile, la discusión en torno a la inexistencia tiene larga data [la autora cita a Rodríguez Grez (1995), pp. 68 y ss.]. En resumen, sus partidarios sostienen que el Código concibe la nulidad como sanción a la omisión de un requisito establecido 'para el valor' del acto (art. 1681), es decir, para su validez, sin referirse a la existencia del acto. Por eso, la consecuencia jurídica de la falta de un requisito de existencia del acto sería precisamente la inexistencia [LECAROS (1997), p. 1]. Agregan que, porque el acto inexistente no produce efecto alguno, el Código ni siquiera previó la inexistencia como modo de extinguir las obligaciones, a diferencia de la nulidad [Claro Solar (1979), p. 581]. Este planteamiento se apoya en el tenor literal de algunas normas que, mediante el empleo de expresiones como 'se mirará como no escrito' o 'no producirá efecto alguno', establecerían una ineficacia ab initio de ciertos actos jurídicos [CLARO SOLAR (1979), pp. 581 y ss.; Vodanovic (1945), pp. 514 y ss.; LeCAROs (1997), pp. 3 y ss.; DucCI (1988), pp. 311 y ss.; VIAL del Río (2003), pp. 237 y ss.]. Finalmente, sostienen que el Código no regula la inexistencia porque 'lo que no existe en la naturaleza no puede ser regulado normativamente' [RodríGuEZ Grez (1995), p. 32]. En cuanto a sus efectos, se dice que a la inexistencia no se aplica el plazo de saneamiento del artículo 1683 C.C., pues la nada no puede sanearse y tampoco es necesaria una sentencia judicial que la declare, pues opera ipso iure [Vial del Río (2003), pp. 237 y ss.; Domínguez (2012), p. 179]”. 
en los artículos 1687 y siguientes del Código Civil chileno ${ }^{114}$, y e) La discusión sobre la naturaleza del plazo para alegar la nulidad absoluta como un plazo de saneamiento del vicio o un plazo de caducidad de la acción ${ }^{115}$.

Sobre esta argumentación básica, la dogmática civil ha discutido sobre la procedencia de la inexistencia como sanción distinta de la nulidad. Sin entrar en la profundidad de este debate, es necesario tener presente la comprensión general de la inexistencia como sanción de los actos jurídicos. En síntesis, los dogmáticos que afirman la procedencia de la inexistencia en Chile señalan que la nulidad es la sanción frente a requisitos de validez de los actos, mientras que la inexistencia se refiere a la omisión de requisitos de existencia de los mismos. Tal como señala San Martín, la posición se funda en "el tenor literal de algunas normas que, mediante el empleo de expresiones como 'se mirará como no escrito' o 'no producirá efecto alguno', establecerían una ineficacia ab initio de ciertos actos jurídicos. Finalmente, sostienen que el Código no regula la inexistencia porque 'lo que no existe en la naturaleza no puede ser regulado normativamente'. En cuanto a sus efectos, se dice que a la inexistencia no se aplica el plazo de saneamiento del artículo 1683 C.C., pues la nada no puede sanearse y tampoco es necesaria una sentencia judicial que la declare, pues opera ipso iure"116. Así, la idea de nulidad de Bernaschina se emparenta con la inexistencia civil en la medida en que la NDP da, según este autor, derecho a resistir el acto ${ }^{117}$. Este derecho resulta semejante a la posibilidad del desconocimiento del acto jurídico que procede frente al acto inexistente según la dogmática civil. Con todo, no resulta claro cuál es el sustento ideológico que posibilita al autor vincular la NDP con la desobediencia. Creo que este punto debe ser investigado con mayor

\footnotetext{
114 SAN MARTín (2015), p. 34.

115 San Martín (2015).

116 SAn Martín (2015), p. 755.

117 Dice: "El derecho de resistencia a la opresión es la consagración política de las ideas del tiranicidio, y es anticipo de la teoría de las nulidades de Derecho Público y de la responsabilidad gubernamental.

"El fundamento de la nulidad no es la injusticia, como ya fue visto, sino la falta de competencia del órgano que dicta la norma viciada. En un ordenamiento jurídico no es posible hablar de normas justas o injustas; lo único que interesa saber es si los actos estatales han sido creados de acuerdo con las normas jurídicas superiores: es decir, interesa la regularidad de la función estatal. En el momento mismo en que el acto excede la competencia de los órganos nace nulo, salvo en los casos en que el Derecho asigne expresamente otro valor a la norma, mientras se decide su regularidad por el órgano competente, como ocurre con la anulabilidad de las leyes. Por esta razón, esta teoría tiene un carácter puramente político y su importancia ha sido disminuida por los medios jurídicos adecuados para restablecer el orden jurídico o para deponer a los funcionarios arbitrarios, como el referéndum, la revocatoria o recall, etc.". BernasChINA (1951), pp. 273-274.
} 
profundidad ${ }^{118}$. Por el momento, desconozco la existencia de obras posteriores de Bernaschina que traten el problema y que puedan clarificar el punto ${ }^{119}$.

Otros puntos de contacto entre el problema de la inexistencia civil y la NDP (más allá del estudio de la versión de Bernaschina) que impactan en las formulaciones posteriores de esta elaboración dogmática son los siguientes ${ }^{120}$ : i) Según la dogmática civil, en Chile no hay una acción meramente declarativa (i. e. imprescriptible) de nulidad civil. Toda acción de nulidad implica los efectos de los artículos 1687 y siguientes del Código. Para una parte de la doctrina esto es expresión de una concepción del legislador: "una acción de nulidad sólo tiene sentido cuando existan consecuencias fácticas que puedan ser revertidas ${ }^{\prime \prime 21}$. Para esta parte de la doctrina, la ausencia de distinción en la regulación de las consecuencias de la nulidad pronunciada judicialmente (art. 1687) es evidencia de que lo relevante para esta acción son las consecuencias prácticas que se hayan producido en razón del acto nulo $^{122}$. La excepción de nulidad civil es, en cambio, imprescriptible. Así, la NDP sería una excepción en el ordenamiento jurídico chileno: una acción

118 En 1958, Bernaschina publicó la segunda edición de su obra Constitución política y leyes complementarias. No he podido encontrar la primera edición de este libro para revisar si el autor realizó cambios a su texto. Hay que considerar que el autor advierte que este texto es una adaptación de su Manual de Derecho Constitucional (editado según el programa de las Escuelas de Derecho) de la cátedra de Derecho Constitucional chileno dictado para los alumnos de la Escuela de Ciencias Políticas y Administrativas de la Universidad de Chile. Bernaschina (1958). En este libro el autor sintetizó su tesis sobre la obediencia al derecho señalando: "La Constitución, en los artículos 4, 23 y 75 establece para el acto mismo producto de la infracción, la sanción de nulidad. Esta nulidad opera de pleno derecho, es decir, se produce en el momento mismo de la infracción y el acto no debe ser obedecido, porque los individuos tienen derecho a resistir los actos contrarios a las normas jurídicas superiores; esos preceptos vienen a confirmar que nuestro régimen político es un sistema de Derecho". Bernaschina (1958), p. 175.

119 Los catálogos de las hemerotecas de las Facultades de Derecho no están suficientemente completos y muchos autores de esa época no citan adecuadamente sus fuentes. Solo hacen menciones generales a autores o corrientes doctrinarias. Es necesario reconocer que completar la historiografía de la NDP requiere llenar el vacío que significa saber con más detalle qué textos se publicaron en este período. El problema bibliográfico es grave: muchas bibliotecas universitarias carecen de libros y revistas antiguos y aquellas que los tienen, los han catalogado de forma muy insuficiente.

120 Estos tópicos son tratados en profundidad en los artículos posteriores.

121 En el Derecho Civil chileno ver San Martín (2015), p. 776. En Derecho Administrativo chileno, desde 2007 con la sentencia Eyzaguirre con Fisco se ha comenzado a discutir la aplicación de la clasificación dogmática de acciones encaminadas solo a declarar la nulidad del acto y acciones de plena jurisdicción con efectos declarativos sobre derechos para resolver algunos asuntos de la NDP. Existen fallos que reconocen explícita e implícitamente la distinción. Ver Bermúdez (2011), pp. 561 y ss.

122 En este sentido, San Martín (2015). 
de nulidad imprescriptible ${ }^{123}$. ii) El plazo para interponer la acción de nulidad civil es de 10 años según el artículo 1683 del Código Civil. Según una parte de la dogmática este es un plazo de saneamiento del vicio. Otros, en cambio, consideran que es un plazo de caducidad de la acción porque el vicio que afecta el acto no desaparece ${ }^{124}$. La inexistencia civil plantea el problema de la posibilidad de fundar una acción que modifique una relación jurídica más allá del plazo de prescripción fijado para acción de nulidad absoluta. Este mismo problema plantea la NDP en versiones posteriores a la de Bernaschina. iii) La dogmática civil sostiene que la nulidad absoluta opera de pleno derecho (aunque esto no implica desconocer las consecuencias fácticas del acto nulo). De hecho, tal como lo resalta el propio Bernaschina la declaración de oficio por el juez permitió aplicar esta figura a actos administrativos, solución que él critica como vimos más arriba.

La expresión del artículo 75 "no serán obedecidas sin ese esencial requisito" asocia la desobediencia a las normas con la nulidad de los artículos $4^{\circ}$ y $23^{125}$. En mi opinión, este paso implica un supuesto teórico no explicitado por el autor: sostener que solo las normas válidas (no nulas) deben ser obedecidas. Ahora bien, esta noción de obediencia es, desde la Teoría Analítica del Derecho, una expresión oblicua para referirse a la no aplicabilidad de la norma en cuestión.

El autor interpreta la frase "sin ese esencial requisito" del artículo 75 como refiriéndose a los requisitos esenciales del acto jurídico del Derecho Civil. Quien interpreta supone que las categorías civiles que ordenan los requisitos de existencia y validez del acto jurídico sirven de matriz teórica para atribuir un significado a la disposición normativa constitucional ${ }^{126}$. Bernaschina interpreta la expresión "sin ese esencial requisito" atribuyéndole, con técnicas

\footnotetext{
${ }^{123}$ La distinción referida en la nota 121 ha generado una distinción desde 2007. Si la pretensión es solo de legalidad, la nulidad es imprescriptible. Si, en cambio, la nulidad se acompaña de pretensiones patrimoniales, la acción prescribe según el artículo 2514 del Código Civil. Mientras se terminaba este trabajo se dictó sentencia en la causa rol $N^{\circ} 18297-2016$, con fecha 23 de junio de 2016. En ese caso la Corte Suprema ha sostenido por primera vez la prescriptibilidad de la acción de nulidad de derecho público.

124 En este último sentido, SAN Martín (2015).

125 Esto implica asociar dos conceptos básicos: nulidad y obediencia. Quizá a través de una noción teórica de validez o de la noción dogmática de inexistencia. Más adelante avanzo una idea sobre este punto.

126 En ese punto es importante recordar que buena parte de la doctrina chilena que cultiva el Derecho Civil ha afirmado que la sanción frente a la omisión de un requisito esencial del acto jurídico es la nulidad absoluta. En dogmática civil, por todos, ver San Martín (2015).
} 
de interpretación sistemático-dogmática (orientada aquí hacia el derecho civil), el significado que ha sido asentado por la dogmática a la ausencia de un "requisito esencial del acto jurídico", según la concordancia entre los artículos 1444, 1681 y 1682 del Código de Bello" ${ }^{127}$.

La expresión "no puede producir efecto alguno" del artículo 23 es concordada con la expresión "no serán obedecidas" del artículo 75. A mi juicio, esta concordancia exige suponer no menos de dos ideas de Teoría del Derecho: i) los actos válidos (no nulos) son eficaces y por ello deben ser obedecidos por los ciudadanos y, a la inversa, los actos inválidos (nulos) son ineficaces y por ello no deben ser obedecidos (existe un derecho a desobedecer para los ciudadanos). Luego, es necesario suponer que la expresión del artículo 23 debe interpretarse tal y como la dogmática civil interpreta el código del ramo para sustentar la inexistencia, por ejemplo, a partir de la interpretación del artículo 1444 entre otras disposiciones ${ }^{128}$.

Nuevamente es necesario insistir en que Bernaschina no es transparente sobre cómo se justifican estos vínculos, es decir, no dice por qué todo acto válido y eficaz (que produce efectos) genera la obligación de obediencia ni por qué todo acto inválido e ineficaz (que no produce efectos) otorga al ciudadano

\footnotetext{
127 Art. 1444. Se distinguen en cada contrato las cosas que son de su esencia, las que son de su naturaleza, y las puramente accidentales. Son de la esencia de un contrato aquellas cosas sin las cuales o no produce efecto alguno, o degenera en otro contrato diferente; son de la naturaleza de un contrato las que no siendo esenciales en él, se entienden pertenecerle, sin necesidad de una cláusula especial; y son accidentales a un contrato aquellas que ni esencial ni naturalmente le pertenecen, y que se le agregan por medio de cláusulas especiales.

Art. 1681. Es nulo todo acto o contrato a que falta alguno de los requisitos que la ley prescribe para el valor del mismo acto o contrato, según su especie y la calidad o estado de las partes.

La nulidad puede ser absoluta o relativa.

Art. 1682. La nulidad producida por un objeto o causa ilícita, y la nulidad producida por la omisión de algún requisito o formalidad que las leyes prescriben para el valor de ciertos actos o contratos en consideración a la naturaleza de ellos, y no a la calidad o estado de las personas que los ejecutan o acuerdan, son nulidades absolutas.

Hay asimismo nulidad absoluta en los actos y contratos de personas absolutamente incapaces.

Cualquiera otra especie de vicio produce nulidad relativa, y da derecho a la rescisión del acto o contrato.

128 Alessandri señala, por ejemplo: "Un acto jurídico es inexistente cuando le falta alguna de las condiciones de existencia y no puede confundirse en doctrina la inexistencia con la nulidad; el acto inexistente no se ha formado, ni ha nacido a la vida del derecho; podrá haber a lo sumo la materialidad del acto [...] Los caracteres jurídicos de la inexistencia son: la inexistencia no necesita ser declarada, ni es menester un pronunciamiento judicial para que se tenga el acto por inexistente, porque si llega a haber litigio sobre el acto inexistente, el juez se limitará a dejar constancia de que el acto no existe, o a rechazar la demanda por falta de prueba [...] En seguida el acto jurídico inexistente no produce efectos jurídicos de ninguna especie; no puede ser saneado por el transcurso del tiempo, ni puede ser ratificado [...]". AlESSANDRI (1930), p. 77.
} 
el derecho a desobedecer ${ }^{129}$. Un intento por disolver el texto analizado en sus componentes más simples implica hacer algunas suposiciones. Creo advertir que Bernaschina estima que el criterio de validez de un acto administrativo es una norma de conducta, en lugar de una definición o norma determinativa. Me atrevo a sostener que Bernaschina confunde la definición de "acto válido" que es una norma determinativa con una metanorma de conducta que obliga a obedecer las normas válidas mismas ${ }^{130}$.

Esta confusión entre el uso cognoscitivo del criterio de validez y el uso prescriptivo que ordena la obediencia a las normas válidas permite explicar desde el punto de vista del teórico del derecho, la relación que Bernaschina formula entre "producir efectos" y "no serán obedecidas". En cambio, desde un punto de vista dogmático, es necesario mostrar que el autor interpreta la expresión "no puede producir efecto alguno" atribuyéndole que ella designa la ineficacia del acto tal como se hace en el Derecho Civil. Afirma esa dogmática que la ineficacia es el género y la nulidad la especie. Agrega entonces que lo que se predica del género puede predicarse de la especie ${ }^{131}$. Además, la expresión "órdenes del Presidente de la República" del artículo 75 es interpretada de forma extensiva y teleológica. La palabra "orden" es interpretada extensivamente como "cualquier norma individual dictada por cualquier órgano de la administración", en lugar de asignarle un significado más restringido como "un tipo específico de norma singular y/o concreta que es dictada por el Presidente de la República".

c.3.) DP-20: "A una disposición se le debe atribuir el significado que resulte de atribuir, a locuciones individuales en aquélla contenidas, el sentido para ellas establecido por la -unánime, mayoritaria o mejor- jurisprudencia"132. Tal como lo destaca Chiassoni, el uso de esta directiva depende de elecciones que debe realizar el intérprete. Por un lado, está la elección de los materiales (las sentencias) relevantes y la fijación de un contexto temporal y, por otro lado, en el caso de identificar diversas interpretaciones-producto, está la selección de la mejor interpretación, habida cuenta el contexto de ejecución de la operación interpretativa. Los criterios prudenciales o ético-

${ }^{129}$ En un trabajo aparte es necesario elucidar qué significa para la dogmática del derecho administrativo chileno la obediencia del acto administrativo.

130 GuAstini (1995).

131 Como es obvio, este razonamiento debe ser usado con cuidado, ya que no todo lo que puede predicarse de la especie puede afirmarse sobre el género. En este tipo de relaciones existe al menos una propiedad diferenciadora que la especie tiene y que el género carece.

132 Chiassoni (2011), p. 102. 
normativos que informan estas elecciones surgen de la ideología jurídica que es preferida por el intérprete. El criterio que parece seguir el autor es, como ya he dicho, una lectura liberal de la constitución entendida según el modelo descriptivo como norma.

c.4.) DP-24: "A una disposición se le debe atribuir el significado sugerido por la pertinente norma final, explícita o implícita, del instituto, sector o subsector al que pertenece la disposición ${ }^{\prime \prime 33}$. Las disposiciones constitucionales interpretadas por Bernaschina son interpretadas de acuerdo a una ratio implícita. Esa ratio es una norma diversa que pertenece al mismo ordenamiento: la supremacía constitucional entendida desde el modelo descriptivo de constitución como norma.

Otro ejemplo del uso de esta directiva es la concordancia del texto de los artículos $4^{\circ}$ y 23 con la última frase del artículo 75 (y no serán obedecidas sin este esencial requisito). Aquí Bernaschina dota al ciudadano de la posibilidad de desobedecer al acto nulo. En síntesis, la interpretación funciona en dos pasos. En el primero se extiende el alcance del artículo 23, pues se supone que regula (con igual grado de generalidad que el artículo $4^{\circ}$ ) la misma noción de nulidad. Un acto que no cumple con el artículo $4^{\circ}$ es nulo, esa nulidad es ipso iure y el acto no genera efecto alguno. Lo confirmaría lo dispuesto por el artículo 23. El segundo paso supone que el artículo 75 regula con el mismo grado de generalidad los efectos de cualquier acto en que se están afectando los requisitos esenciales (i. e. es un acto nulo). Esta concordancia supone una ratio sobre la obediencia al derecho que afirma que solo los actos válidos tienen como efecto el deber de ser obedecidos por los ciudadanos y, entonces, que cualquier acto nulo puede no ser obedecido. Así, la redacción del artículo 75 sería solo la instanciación de esta ratio sobre la obediencia al derecho de raigambre liberal.

La interpretación de Bernaschina está orientada por una supuesta ratio, porque enfatiza que el propósito a la dictación de cualquier norma individual es generar la obligación de obedecer en los ciudadanos tal y como si se tratase de una ley. Así, la expresión "no puede producir efecto alguno" es interpretada como "no producen el efecto de generar la obligación de obedecer" (porque no son normas válidas). Este es un punto abierto, ya que en 1958, Bernaschina publicó la segunda edición de su obra Constitución Política y leyes complementarias, en donde trata el asunto en un párrafo muy

133 Chiassoni (2011), p. 104. 
breve $^{134}$. No profundizo en este punto porque se aparta del objetivo del trabajo y merece un estudio particular ${ }^{135}$.

\subsubsection{Directivas secundarias}

En lo relativo a las directivas secundarias, el trabajo analizado parece seguir un código monista de directivas selectivas, es decir, un código que prescribe que el intérprete use un conjunto unitario de directivas primarias (directivas primeras de interpretación literal sistemática). Las directivas procedimentales puras usadas no parecen permitir al intérprete seleccionar las directivas primarias según sea el contexto de interpretación. A contrario, la argumentación de Bernaschina es formulada a partir de una directiva procedimental pura ordenadora que "prescribe al intérprete la utilización, siempre y en todo caso, de todas las directivas primarias indicadas por la directiva selectiva"136. A su turno, no hay evidencias de que el autor analizado utilice directivas procedimentales axiológicas que fijen una jerarquía axiológica entre resultados interpretativos que puedan obtenerse a partir de diferentes conjuntos de directivas primarias.

Sobre las directivas preferenciales es necesario decir que la argumentación analizada se sustenta en no menos de tres directivas preferenciales negativas, como las siguientes: 1) "DPI-9 [...] prohíbe derivar de las disposiciones, como sus significados correctos all things considered o habida cuenta de todo, normas explícitas que den lugar a una desarmonía en la estructura

${ }^{134}$ En este libro el autor sintetizó su tesis sobre la obediencia al derecho señalando: "La Constitución, en los artículos 4, 23 y 75 establece para el acto mismo producto de la infracción, la sanción de nulidad. Esta nulidad opera de pleno derecho, es decir, se produce en el momento mismo de la infracción y el acto no debe ser obedecido, porque los individuos tienen derecho a resistir los actos contrarios a las normas jurídicas superiores; esos preceptos vienen a confirmar que nuestro régimen político es un sistema de Derecho". BernASCHINA (1958), p. 175. No he podido encontrar la primera edición de este libro para revisar si el autor realizó cambios a su texto. Hay que considerar que el autor advierte que este texto es una adaptación de su Manual de Derecho Constitucional (editado según el programa de las Escuelas de Derecho) para el programa de la cátedra de Derecho Constitucional chileno dictado para los alumnos de la Escuela de Ciencias Políticas y Administrativas de la Universidad de Chile.

135 Una opción de reconstrucción diferente de la obra de Bernaschina es sostener que aquí hay un símil con la idea de la dogmática civil que sostiene la procedencia de la inexistencia en el derecho chileno. Esta dogmática señala que dado que la inexistencia opera de pleno derecho y no requiere de declaración judicial, las partes pueden desconocer el acto jurídico inexistente. Así, la desobediencia postulada por Bernaschina para la NDP es análoga al desconocimiento civil. Otra alternativa de lectura del trabajo del autor es sostener que la ausencia de una obligación de obedecer permite derivar la existencia de un derecho a desobedecer, lo que implica sostener la tesis de un sistema jurídico completo y clausurado.

136 ChIASSONI (2011), p. 113. 
del discurso de las fuentes o que, en cualquier caso, concuerden mal con la parte del discurso de las fuentes en la que han sido colocadas"137; 2) "DPI-11 [...] prohíbe al intérprete atribuir a una disposición un significado no compatible con las (por hipótesis) pertinentes construcciones dogmáticas en la materia, subsector o sector del derecho positivo al que la disposición hace referencia"138; 3) DPI-11a: Se prohíbe atribuir a una disposición un significado que resulte de atribuir, a locuciones individuales en aquella contenidas, un sentido para que ellas no esté establecido por la -unánime, mayoritaria o mejor- jurisprudencia ${ }^{139}$. Es importante destacar que estas directivas son endosistemáticas, porque afirman la compatibilidad de las diversas normas que forman el ordenamiento. Tras ellas hay una tesis sobre la coherencia del derecho.

En el caso de directivas preferenciales positivas, es posible identificar no menos de tres directivas: 1) "DPC-11: El significado técnico-jurídico de una disposición prevalece sobre su diferente significado ordinario"140; 2) "DPC14/-15-16: entre dos o más significados de una misma disposición debe preferirse el que realice i) la mejor armonía topográfica, y/o resultados más compatibles - desde un punto de vista de su ii) congruencia instrumental o iii) axiológica-con otras normas, formal o axiológicamente superiores del sistema positivo o de otro sistema normativo relevante (moral positiva, derecho natural, etc.)"141 y 3) "DPC-17: entre dos o más significados de una misma disposición debe preferirse el que resulte más compatible con las pertinentes construcciones dogmáticas para la materia, el subsector o bien el sector del derecho positivo a la cual la disposición hace referencia'142.

\subsubsection{Directivas axiomáticas}

El código hermenéutico analizado es ecléctico e incluye no menos de dos directivas como las siguientes: "(DAE): La interpretación de las disposiciones debe ser llevada a cabo sobre la base de las directivas primarias y secundarias que aseguren el máximo grado posible de certeza del derecho en su aplicación judicial (y/o el máximo grado posible de subordinación del

\footnotetext{
137 ChIASSONI (2011), p. 123.

138 ChIASSONI (2011), p. 123.

139 Chiassoni (2011), p. 123. El autor no formula esta directiva, sino que deja al lector su formulación, de ahí el nombre DPI-11a.

140 Chiassoni (2011), p. 128.

141 Chiassoni (2011), p. 129.

142 Chiassoni (2011), p. 129.
} 
intérprete a la ley"143 y "(DAEC): La interpretación de las disposiciones debe ser llevada a cabo sobre la base de directivas primarias y secundarias que: a) Sean conformes a la naturaleza del documento objeto de interpretación"144. Dentro de esta directiva axiomática es necesario considerar la adhesión al modelo descriptivo de constitución como norma que "determina" la naturaleza del documento constitucional y la inexistencia de diferencias cualitativas entre la interpretación de disposiciones normativas de rango constitucional y las de rango legal.

Finalmente, en relación con el resultado de la interpretación textual analizada, es necesario considerar que la frase atributiva absoluta del artículo $4^{\circ}$ es interpretada con una adición pragmática ${ }^{145}$ : la NDP es el género y las nulidades administrativas constituyen la especie ${ }^{146}$. Este argumento de disociación taxonómica construye dos tipos de casos. Uno de ellos es un subconjunto en relación con el otro y permite justificar que existan rasgos comunes y diferenciadores entre ambos conjuntos de casos.

\begin{tabular}{|l|l|}
\hline \multicolumn{1}{|c|}{$\begin{array}{c}\text { Categorías de análisis - Cuadro resumen } \\
\text { Mario Bernaschina González }\end{array}$} \\
\hline Filosofía política & $\begin{array}{l}\text { Liberal. Ello en la medida en que el propósito de la argumentación es dotar } \\
\text { al ciudadano de mayores resguardos frente al actuar de la Administración. } \\
\text { Esta idea debe compensarse con un presupuesto: la ausencia de crítica a la } \\
\text { inexistencia de tribunales contencioso-administrativos implica aceptar que es } \\
\text { necesario que tribunales especiales juzguen a la administración y, entonces, } \\
\text { concederle un estatus de privilegio frente al ciudadano. }\end{array}$ \\
\hline Ideología jurídica & Positivista. \\
\hline Política del derecho & $\begin{array}{l}\text { Orientación hacia el derecho público en términos de disociar el uso de la } \\
\text { nulidad absoluta civil para sancionar la ilegalidad de actos administrativos. } \\
\text { Al mismo tiempo, orientación hacia el derecho privado en razón del uso de } \\
\text { categorías dogmáticas civiles y en relación con la construcción de una ana- } \\
\text { logía parcial entre la ilegalidad del acto administrativo y la inexistencia civil, } \\
\text { i. e. postular la posibilidad de desconocer y resistir el acto nulo. }\end{array}$ \\
\hline
\end{tabular}

143 Chiassoni (2011), p. 136.

${ }^{144}$ ChIASSONI (2011), p. 137.

145 Sobre las adiciones pragmáticamente necesarias ver CHIASSONI (2011), p. 143.

146 BernasChina (1949), pp. 551-552. Las principales cualidades de estas nulidades son, según el mismo autor, las siguientes: "Por ningún motivo las partes podrían ratificar el vicio que invalida un acto y no se sanea ni siquiera por el transcurso del tiempo, pues el acto nulo no puede producir efecto alguno como acto jurídico estatal desde el momento en que no puede ser imputable al Estado, como ordenamiento jurídico, porque ha sido dictado fuera de ese ordenamiento con infracción de las normas jurídicas.

"Asimismo, no es necesario que ella sea declarada por la autoridad, salvo excepciones expresas que la ley establece, de manera que antes y después de su declaración, si es que procede y se hace, el acto no puede producir efecto alguno". BernasCHINA (1949), pp. 551-552. 


\section{Categorías de análisis - Cuadro resumen} Mario Bernaschina González

\begin{tabular}{|l|}
\hline $\begin{array}{l}\text { Texto normativo inter- } \\
\text { pretado }\end{array}$ \\
\hline $\begin{array}{l}\text { Modelo de constitu- } \\
\text { ción }\end{array}$ \\
\hline $\begin{array}{l}\text { Conceptos teórico- } \\
\text { dogmáticos }\end{array}$ \\
\hline Código hermenéutico \\
\\
\hline $\begin{array}{l}\text { Norma constitucional } \\
\text { (formulación de la } \\
\text { NDP) }\end{array}$
\end{tabular}

Artículos 4ㅇ, 23 y 75 de la Constitución de 1925.

Descriptivo de constitución como norma. El autor hace referencias a Kelsen (la citas de Bernaschina a Kelsen deberían ser observadas con más detalle). En alguna medida defiende un modelo descriptivo de la constitución como norma. Declara que la teoría de las nulidades administrativas debe ubicarse en la Teoría del Estado.

Validez, producción de efectos (eficacia), competencia, obediencia, inexistencia, nulidad absoluta civil, desconocimiento del acto, nulidad en el derecho público, nulidad de derecho público, nulidad administrativa.

\section{- Directivas}

o Primarias. DP-5, DP-15, DP-20, DP-24.

o Secundarias. DPI-9, DPI-11, DPI-11a, DPC-14/-15-16, DPC-17.

o Axiomáticas. DAE, DAEC.

- Interpretación textual de las siguientes expresiones:

o "todo acto en contravención a este artículo es nulo".

o "es nula de derecho".

o "no puede producir efecto alguno".

o "no serán obedecidas sin este esencial requisito".

El texto de la constitución fija una nulidad genérica en relación con la nulidad administrativa, que afecta al acto ab initio. Esta nulidad tiene rasgos semejantes a la inexistencia civil. El texto constitucional es interpretado como fijando no menos de tres normas:

a) una regla prohibitiva al modo del Derecho Civil, cuya infracción está sancionada con nulidad.

b) una regla constitutiva que señala que solo el acto válido es imputable al Estado.

c) una regla permisiva que da derecho al ciudadano a resistir el acto nulo.

El texto de la Constitución, aunque fija la nulidad, no es directamente aplicable (no consagra una acción constitucional).

Información adicional

- No afirma la continuidad de la Constitución de 1925 con la de 1833.

- No usa la noción de "principio" más que para referirse a la idea de "principio de las nulidades administrativas".

- La interpretación constitucional no presenta problemas interpretativos específicos que la diferencien de la interpretación de la ley (sea lo que signifique esa expresión).

- Tras la obra de Bernaschina están ausentes la mayor parte de los rasgos de la constitucionalización del ordenamiento fijados por Guastini (2003).

- Además, el autor no se plantea problemas orientados a la plausibilidad y consecuencias del litigio derivado del acto nulo, como la prescripción o la indemnización de los perjuicios.

o No se discute la prescriptibilidad de la acción.

o No se discute la taxatividad de las causales de nulidad de derecho público.

o No se discute la clasificación de acciones que pretenden la nulidad y acciones que pretenden la declaración de derechos (plena jurisdicción). 


\section{Conclusiones}

La teoría (descriptiva) de la interpretación constitucional y de la interpretación de otros textos normativos (vigentes en un momento determinado) consiste en analizar las técnicas efectivamente utilizadas por jueces y juristas cuando interpretan las fuentes ${ }^{147}$. En Chile es pacífico sostener que la NDP es derecho administrativo vigente. Sin embargo, hasta ahora no ha realizado un análisis detallado de cómo los juristas formularon la argumentación dogmática que le da sustento a la interpretación correctora del texto constitucional. En el presente artículo expuse un ejercicio de este tipo de teoría descriptiva sobre la interpretación constitucional. Elegí la versión de Bernaschina de la NDP por tratarse de la primera formulación de esta figura según afirma la propia doctrina. Para ejecutar este análisis usé las categorías de la Escuela Genovesa y examiné con detalle el código hermenéutico y las categorías dogmáticas que componen el discurso dogmático en cuestión. Las conclusiones pueden organizarse en dos niveles. Las primeras son enunciados sobre el objeto de estudio analizado. Las segundas son enunciados más generales sobre el total de la investigación y, en este sentido, son parciales. En la medida en que el cuadro resumen de la página anterior sintetiza las conclusiones de primer nivel, no creo que valga la pena repetirlas aquí. Por ello, en lo que sigue me concentro solo en las conclusiones de segundo nivel.

El objetivo metadogmático ha sido completado. Ha sido posible describir el trabajo de Bernaschina y reconstruir su versión de la NDP. Es decir, su posición sobre la ideología, la política del derecho, su modelo de constitución y el código hermenéutico que usó para fundar la interpretación correctora de las disposiciones constitucionales de los artículos $4^{\circ}, 23$ y 75 de la Constitución de 1925 que dio origen a la NDP. Es importante resaltar que este código se vincula con una red de conceptos teórico-dogmáticos que sirven de trasfondo para el trabajo interpretativo. Esta red conceptual y su uso en la actividad interpretativa no son fáciles de observar a simple vista. El ejercicio descriptivo ha requerido asociar componentes de Derecho Civil, Constitucional, Administrativo y Teoría del Derecho. Aunque no hay dudas de que puede ser perfectible, el método formulado ha sido fructífero para elucidar, por ejemplo, cómo las nociones dogmáticas (inexistencia, nulidad, desconocimiento del acto, entre otras) y las teóricas (validez, producción de efectos o eficacia, obediencia) forman una red conceptual que soporta el peso de la argumentación. Esta descripción es importante porque permite identificar una versión de la NDP mediante el reconocimiento del modo en que justifica

147 Para la interpretación constitucional, GUASTINI (2010), p. 52. 
la interpretación de las disposiciones normativas de la Constitución, fijando un punto de comparación para entender cómo se ha formado el Derecho Administrativo nacional y con qué técnicas y conceptos este derecho es "derecho constitucional que ha de ser desarrollado y completado"148.

El objetivo metodológico se ha logrado de manera parcial. Para completarlo las categorías deben ser usadas para comparar las obras de más juristas sobre este punto y así determinar cuáles son y cómo se organizan los conceptos y las técnicas de interpretación en cada una de las argumentaciones estudiadas. Esto es importante, porque probaría la tesis genovesa que afirma que las elecciones hermenéuticas ( $y$, como no, las dogmáticas) están determinadas por las decisiones filosóficas, ideológicas y políticas del intérprete. Es objetivo del segundo y tercer artículo de esta serie testear esta idea a través de la comparación de los trabajos de Soto, Pierry, Silva y luego de dogmáticos que intervinieron sobre la NDP después del año 2000 e identificar el canon de aceptabilidad racional que provocó que la comunidad jurídica chilena sostuviese la procedencia de una acción de nulidad sin texto constitucional expreso.

\section{Bibliografía CitADA}

AlesSANDRI, Arturo (1930): Derecho civil, segundo año. De los contratos. Versión taquigráfica (Santiago, Imprenta Editorial Bellas Artes).

AlesSANDri, Arturo (1949): La nulidad y la rescisión en el Derecho Civil chileno

(Título XX del Libro IV del Código Civil) (Santiago, Imprenta Universitaria).

ANDRADE, Carlos (1963): Elementos de derecho constitucional chileno (Santiago, Editorial Jurídica de Chile).

Aytwin, Patricio (1958): Apuntes de derecho administrativo. Apuntes de clases (Santiago, Editorial Universitaria S.A.), tomo III.

BARBERIS, Mauro (1987): "Tarello, Lideologia e lo spazio della teoria", en: Materiali per una storia della cultura giuridica (XVII, № 2), pp. 317-355.

BARBERIS, Mauro (2011): "Un poco de realismo sobre el realismo genovés", en: Ferrer, Jordi y Ratti, Giovanni (eds.), El realismo jurídico genovés (Barcelona, Marcial Pons), pp. 201-216.

Bermúdez, Jorge (2008): "El principio de legalidad y la nulidad de derecho Público en la Constitución Política. Fundamentos para la aplicación de

148 Me refiero a la frase de Werner "konkretisiertes Verfassungrecht" traducida tradicional y malamente como "Derecho constitucional concretizado". WeRnER (1959), p. 527. 
una solución de Derecho Común", en: Revista de Derecho Público (vol. 70), pp. 273-285.

Bermúdez, Jorge (2010): "Estado actual de control de legalidad de los actos administrativos: ¿Qué queda de la nulidad de derecho público?", en: Revista de Derecho de la Universidad Austral de Chile (vol. 23, № 1), pp. 103-123.

Bermúdez, Jorge (2012): Las relaciones entre el derecho administrativo y el derecho común. Derecho positivo, doctrina y jurisprudencia (Santiago, Editorial LegalPublishing).

Bernaschina, Mario (1943): Constitución Política de la República de Chile. Promulgada el 18 de septiembre de 1925. Anotada y concordada (Santiago, Ediciones de la Universidad de Chile).

Bernaschina, Mario (1949): "Bases jurisprudenciales para una teoría de las nulidades administrativas", en: Boletín del seminario de Derecho Público de la Escuela de Ciencias Jurídicas y Sociales de la Universidad de Chile (Año XVIII, Nos. 45-48), pp. 549-559.

Bernaschina, Mario (1950): "Bases jurisprudenciales para una teoría de las nulidades administrativas", en: Boletín de la Contraloría General de la República (Tomo 2), pp. 401-412.

Bernaschina, Mario (1951): Manual de derecho constitucional (Santiago, Editorial Jurídica de Chile), tomo I.

BernasChInA, Mario (1955): Repertorio de legislación y jurisprudencia chilenas. Leyes administrativas sobre municipalidades (Santiago, Editorial Jurídica de Chile).

Bernaschina, Mario (1958): Constitución Política y leyes complementarias. (Santiago de Chile, Editorial Jurídica de Chile).

Bernaschina, Mario y Pinto, Fernando (1945): Los constituyentes de 1925. Trabajo colectivo del Seminario de Derecho Público con una introducción de su director Profesor D. Aníbal Bascuñán Valdés (Santiago, Universidad de Chile), vol. 1.

Bologna, Germán (1962): El acto administrativo irregular. Memoria de Prueba (Santiago, Universidad de Chile).

CASSESE, Sabino (2014): Derecho Administrativo: historia y futuro (Madrid, Instituto Nacional de Administración Pública).

ChIASSONI, Pierluigi (2011): Técnicas e interpretación jurídica. Breviario para juristas (Barcelona, Marcial Pons). 
ComanducCl, Paolo (2007): "Modelos e interpretación de la constitución", en: Carbonell, Miguel (ed.), Teoría del neoconstitucionalismo (Madrid, Trotta-UNAM).

Ferrada, Juan Carlos (2005): "El Recurso de Protección como mecanismo de control contencioso administrativo", en: V.V.A.A. Ferrada, Juan Carlos (coord.), La Justicia Administrativa (Santiago,Editorial LexisNexisUniversidad Austral de Chile), pp. 129-164.

Fiamma, Gustavo (1986a): "La acción constitucional de nulidad: un supremo aporte del constituyente de 1980 al derecho procesal administrativo", en: Revista de Derecho y Jurisprudencia (t. LXXXIII, $1^{\text {a }}$ parte, № 3, sección Derecho), pp. 123-156.

FueNTES, Claudio (2010): "Transición auto-contenida. Elites políticas y reformas constitucionales en Chile (1990-2010)". Disponible en: http://www.icso.cl/ images/Paperss/paper_fuentes.pdf [visitado el 17/01/2015].

Guastini, Riccardo (1995): "Normas supremas", en: Doxa (Nºs. 17-18), pp. 257-270.

GuastinI, Riccardo (2000a): Estudios sobre interpretación jurídica (Ciudad de México, Porrúa).

GuastinI, Riccardo (2000b): "La constitucionalización del ordenamiento jurídico: el caso italiano", en: CARBOnelL, Miguel (coord.), Neoconstitucionalismo(s) (Madrid, Trotta), pp. 49-74.

GuastinI, Riccardo (2010): Teoría e ideología de la interpretación constitucional (Madrid, Trotta).

Guerra, José Guillermo (1929): La Constitución de 1925, Anales de la Universidad de Chile (Santiago, Establecimientos Gráficos "Balcells \& Co.").

JARA, Jaime (2004): La nulidad de derecho público ante la doctrina y la jurisprudencia (Santiago de Chile, Editorial Libromar).

LEÓN, Avelino (1983): El objeto en los actos jurídicos (Santiago, Editorial Jurídica de Chile).

Letelier, Raúl (2013): "Presupuestos metodológicos para el análisis de la nulidad en el Derecho Administrativo", en: FerRADA, Juan Carlos (coord.), La nulidad de los actos administrativos en el derecho chileno. IX Jornadas de Derecho Administrativo. Asociación de Derecho Administrativo (ADAD) (Santiago, LegalPublishing - Thomson Reuters), pp. 11-28.

LIRA, Elizabeth y Loveman, Brian (2014): Poder Judicial y conflictos políticos (Chile: 1925-1958) (Santiago, Editorial de la Universidad Alberto Hurtado y LOM). 
NúÑEz, Álvaro (2012): “¿Deciden los jueces por razones políticas?”, en: Revista Jurídica (Vol. 9, 2), pp. 13-31.

NúÑ̃z, Álvaro (2016): "Conceptos jurídicos dogmáticos: una aproximación (iusrealista)", en: Revus. Journal for constitutional theory and philosophy of law, en prensa.

Olguín, Hugo (1961): Extinción de los actos administrativos, revocación, invalidación y decaimiento (Santiago, Editorial Jurídica de Chile).

Pfeffer, Emilio (2005): "La nulidad de derecho público; tendencias jurisprudenciales", en: Revista de Derecho Público (vol. 67), pp. 129-144.

Piccinı, Doris (1968): Teoría del decaimiento de los actos administrativos. Memoria de Prueba (Santiago, Universidad de Chile).

RaJevic, Enrique y Garcés, María Fernanda (2009): "Control de legalidad y procedimiento de toma de razón", en: Un mejor Estado para Chile, planificación, control y evaluación de la acción del Estado. Disponible en: http://politicaspublicas.uc.cl/wp-content/uploads/2015/02/capitulo-4-planificacioncontrol-y-evaluacion-de-la-accion-del-estado.pdf [visitado el 19/01/2015], pp. 613-646. Al parecer otra versión en: http://www.derecho.uahurtado.cl/ documentos/Rajevic-Garces.pdf [visitado el 19/01/2015].

RoldÁn, Alcibíades (1917): Elementos de Derecho Constitucional de Chile, Segunda edición corregida y aumentada (Santiago-Valparaíso, Soc. ImprentaLitográfica Barcelona).

San Martín, Lilian (2015): "La teoría de la inexistencia y su falta de cabida en el Código Civil chileno", en: Revista Chilena de Derecho (Vol. 42, № 3), pp. 745-784.

TARELLO, Giovanni (1975): Materiali per un storia della cultura giuridica (Bologna, Il Mulino).

TARello, Giovanni (1976a): "Réplica (Il diritto como ordinamento)", en: OreCCHIA, R. (editor), II diritto come ordinamento / Informazione e verità nello stato contemporaneo: atti del X Congresso Nazionale di Filosofia giuridica e politica (Bari, 3-5 Ottobre 1974). (Milano, Giuffrè), pp. 234-237.

TARELLo, Giovanni (1976b): Storia della cultura giuridica moderna: Assolutismo e codificazione del diritto (Bologna, Il Mulino).

TARello, Giovanni (2002a): Teorías e ideologías en derecho sindical (Granada, Comares).

TARello, Giovanni (2002b): "Actitudes doctrinales y cambios estructurales de la organización jurídica", en: Cultura Jurídica y Política del Derecho (Granada, Comares), pp. 385-395. 
Tarello, Giovanni (2002c): "Sociología en la jurisprudencia", en: Cultura Jurídica y Política del Derecho (Granada, Comares), pp. 439-453.

TARello, Giovanni (2002d): "La escuela de la exégesis y su difusión en Italia", en: Cultura Jurídica y Política del Derecho (Granada, Comares), pp. 73-112.

TARello, Giovanni (2002e): "La reglamentación constitucional de la propiedad", en: Cultura Jurídica y Política del Derecho (Granada, Comares), pp. 261-341.

Tarello, Giovanni (2002f): "Ideologías del siglo XVIII sobre la codificación y estructura de los códigos", en: Cultura Jurídica y Política del Derecho (Granada, Comares), pp. 43-64.

TORRETTI, Roberto (2010): "La proliferación de los conceptos de especie en la biología evolucionista", en: Theoria (69), pp. 325-377.

TORRETTI, Roberto (2012): Inventar para entender (Santiago, Ediciones de la Universidad Diego Portales).

Werner, Frizt (1959): "Verwaltungrecht als Konkretisiertes Verfassungsrecht", en: Deutsches Verwaltungsblatt, pp. 527-533.

YABER, Yamil (1962): Modificación y revocación del decreto supremo, Memoria de Prueba (Santiago, Universidad de Chile).

Zapata, Patricio (2006): Reproducción de su participación en Simposio: Reformas del año 2005 a la Constitución Política de la República de Chile. Disponible en: http://www.anuariocdh.uchile.cl/index.php/ADH/article/ viewFile/13372/13643 [visitado el 18/01/2017]. 